\title{
OUVRIERS, PROLETARJAT, CZY STAN CZWARTY? KONCEPTUALIZACJE KLASY ROBOTNICZEJ W KRĘGACH POLSKIEJ LEWICY (1832-1892)
}

\section{PiOTR KULIGOWSKI}

\begin{abstract}
Abstrakt: Autor bada sposoby konceptualizacji klasy robotniczej w kręgach polskiej lewicy od powstania Towarzystwa Demokratycznego Polskiego (1832) aż do zjazdu paryskiego, w efekcie którego utworzono Polską Partię Socjalistyczną (1892). Pierwsza część artykułu poświęcona jest okresowi 1832-1846. Zawiera ona analizę pierwszych użyć pojęć takich jak „proletarjat” w polskim języku politycznym, a także ukazuje refleksyjny charakter transferu pojęć politycznych z języka francuskiego. W drugiej części tekstu (1846-1878) z jednej strony podejmowana jest problematyka spowolnienia procesu adaptacji nowych pojęć odnoszących się do klasy robotniczej, z drugiej zaś strony - pokazana zostaje zmiana pokoleniowa zachodząca w kręgach polskiej lewicy. W trzeciej części omówione są lata 1878-1892. Jej celem jest wskazanie, że dopiero w przypadku schyłku dziewiętnastego wieku można mówić o sytuacji, w której zmiany pojęciowe były rezultatem sumowania doświadczeń polskiej wspólnoty. Robotnicy w tym ostatnim okresie ukazywani byli jako ofiary kapitalizmu, ale także jako ta klasa, która ów system obali.
\end{abstract}

Słowa kluczowe: XIX wiek, klasa robotnicza, pojęcie polityczne, pojęciowa zmiana, polityczna nowoczesność 
Proletariat w kręgach zachodnioeuropejskiej lewicy socjalistycznej, począwszy od połowy dziewiętnastego wieku, przez wiele dekad traktowany był jako uniwersalny podmiot polityczny, mający - poprzez wyzwolenie siebie - na trwałe pogrzebać kapitalistyczne formy organizacji pracy i produkcji, oparte na wyzysku pracy najemnej przez kapitał. Popularność tego pojęcia wynikała ze specyficznych okoliczności społeczno-politycznych, takich jak rewolucja przemysłowa i związane z nią walki społeczne, urbanizacja, wzrost znaczenia życia miejskiego itp., wpisując się tym samym w ogólną tendencję modernizacyjna. Zupełnie inaczej, ze względu na odmienne uwarunkowania, konceptualizacja klasy robotniczej przebiegała poza zachodnimi centrami kapitalizmu. W obrębie polskiego imaginarium politycznego proces ten zachodził w sposób nieliniowy, a prześledzenie go wieść może do przemyślenia realiów kształtowania się polskiej nowoczesności.

Temat ten jak dotąd nie doczekał się wyczerpującego studium. Jednak już w 1959 roku Bronisław Baczko, na marginesie rozważań o Henryku Kamieńskim, postulował przeanalizowanie toku wchodzenia do polszczyzny pojęć takich jak proletariat czy klasa robotnicza i ich znaczenia dla rozwoju polskich idei politycznych w dziewiętnastym wieku (Baczko 1959, 569). W niewielkim stopniu zadanie to wykonał Franciszek Pepłowski w najważniejszym jak dotąd opracowaniu poświęconym polskim pojęciom społecznopolitycznym w okresie oświecenia i romantyzmu. W interesującej mnie sferze autor wyróżnił takie pojęcia jak proletariat, klasa robocza, robotnik, a także lud z następującymi dookreśleniami: przemysłowy, rzemieślniczy, pracowity i wyrobniczy (Pepłowski 1961). Praca Pepłowskiego niewatpliwie imponuje swym zakresem, gdyż opracowanie tak obszernego problemu w oparciu o szeroki korpus źródeł przez jednego tylko badacza, w dodatku pozbawionego cyfrowych narzędzi analizy, świadczy o jego gigantycznej skrupulatności i włożonym wysiłku. Niemniej przy rozważaniu sposobów konceptualizacji klasy robotniczej skrócenie perspektywy do schyłku epoki romantyzmu w istotny sposób zawęża pole widzenia.

Dlatego też w moim tekście badam proces konceptualizacji klasy robotniczej w okresie od utworzenia Towarzystwa Demokratycznego Polskiego do powstania Polskiej Partii Socjalistycznej. Lata 1832-1892 obejmuja, jak sądzę, wszystkie najistotniejsze procesy zmian w pojęciowości politycznej, w ramach których ugruntowało się postrzeganie robotników w nowoczesnych kategoriach. Uzasadniając przyjęcie wskazanych ram czasowych, warto nadmienić, że z powodu specyfiki polskiej historii Koselleckowskie pojęcie Sattelzeit, tłumaczone jako „czas siodła” lub „czas przełęczy”, nie znajduje w tym przypadku zastosowania z uwagi na fakt, że kształtowanie się języka politycznego zachodziło tu w zupełnie innych realiach niż w badanym przez Reinharta Kosellecka kontekście niemieckim. Na gruncie polskim odnotować można nie tyle ciagły proces przemian języka, co raczej pewne okresy przyspieszonych przemian, wynikające z określonych, sprzyjających 
uwarunkowań (np. braku cenzury, liberalnego prawa prasowego, środków finansowych na druk czy dystrybucję pism, a nawet dostępności papieru). Jednym z takich okresów jest oświecenie, kiedy to takie pojęcia jak naród, społeczeństwo czy państwo wysunęły się na pierwszy plan (Trencsenyi et al. 2016, 28). Dla prowadzonych tu rozważań przełom osiemnastego i dziewiętnastego wieku ma jednak marginalne znaczenie, gdyż nie dokonały się wtedy zasadnicze zmiany w sposobach postrzegania robotników. Drugi z takich okresów to, moim zdaniem, pierwsze lata Wielkiej Emigracji, które cechowały się niespotykaną wcześniej dynamiką życia politycznego, uchwytną np. dzięki ilościowemu zestawieniu wydawanych wówczas tytułów prasowych (Kalembka 1977; Kolasa 2013). Wówczas także dokonało się wiele pojęciowych zmian $\mathrm{w}$ interesującej mnie sferze. Trzeci wreszcie $\mathrm{z}$ takich progowych momentów to ostatnie dekady dziewiętnastego wieku. Ten ostatni okres różnił się jakościowo od lat trzydziestych i czterdziestych, kiedy to przekształcenia języka dokonywały się przede wszystkim poprzez transfery z języka francuskiego. Schyłek wieku charakteryzował się bowiem przeobrażeniami zachodzącymi w polszczyźnie dzięki bezpośredniemu kontaktowi ze zjawiskami charakterystycznymi dla politycznej nowoczesności. Dlatego też rok powstania PPS-u to symboliczne uwieńczenie procesu ugruntowywania się pojęcia proletariatu jako centralnej kategorii dla socjalistycznego myślenia. O niejednolitości tego procesu świadczy z jednej strony fakt pewnego spowolnienia owej pojęciowej zmiany, który staje się uchwytny po 1846 roku, z drugiej zaś - wielka różnorodność pojęć stosowanych w celu określenia klasy robotniczej. By oddać tę różnorodność jak najpełniej, zgodnie z procedurą zalecana przez Kosellecka prowadzę analizę semazjologiczna, ale przede wszystkim onomazjologiczna. Co więcej, staram się bazować - tak często, jak to możliwe - na oryginalnych wydaniach tekstów źródłowych. Dlatego też wiele przytaczanych w artykule cytatów zachowuje pisownię oryginalną, o czym za każdym razem komunikuję, umieszczając informację w nawiasie kwadratowym - [p.o.]. Wspomnieć wypada także, że podstawowym kluczem w doborze bazy źródłowej było uczynienie jej możliwie różnorodną. Starałem się więc pracować na zróżnicowanych materiałach: od oficjalnych programów politycznych, poprzez broszury, powieści, pojedyncze artykuły i interwencje publicystyczne, aż po źródła epistolarne, w szczególnych przypadkach także tłumaczenia i zasób słownikowy. Procesem, który chcę uchwycić w ramach prowadzonych tu rozważań, jest pojęciowa zmiana zachodząca w odniesieniu do kształtującej się klasy robotniczej. Jak sugeruje James Farr, pojęciowa zmiana może być rozumiana jako:

kreatywny rezultat procesu, w którym polityczni aktorzy próbują rozwiązać określone problemy, na które napotykają, próbując zrozumieć i zmieniać świat wokół nich. By dostrzec te problemy, musimy zwrócić uwagę na oczywista, wspomniana powyżej cechę języka: pojęcia nigdy nie są przetrzymywane lub używane w izolacji, ale w konstelacji, która tworzy całościowe programy lub systemy przekonań. Te programy 
lub systemy przekonań są teoriami i ci, którzy je posiadają, są teoretykami - oczywiście o różnych stopniach artykulacji i wyrafinowania. Teorie, z kolei, mogą być rozumiane jako intencyjne lub racjonalne próby rozwiazzania praktycznych i spekulatywnych problemów, generowanych $\mathrm{w}$ lub pomiędzy politycznymi przekonaniami, akcjami i praktykami (Farr 1989, 33).

Pojęciowa zmiana nie jest zatem nigdy kwestią wyłącznie teoretyczną, ale wiąże się z namacalnymi zjawiskami z przestrzeni politycznej. Przemiany języka interferują z przekształceniami zachodzącymi w kontekście społeczno-gospodarczym. Procedura badawcza, jaka jest analiza historia pojecć, pozwala śledzić, na ile język owe zmiany rejestrował, a na ile na nie bezpośrednio wpływał (Richter 1996, 10).

Pojęciowe zmiany nigdy nie odbywały się w próżni. Transfery, przesunięcia i dookreślenia znaczeniowe takich pojęć jak proletariat czy klasa robotnicza wiązały się z procesem upodmiotowienia robotników jako grupy społecznej, obserwowanym najpierw we Francji czy w Wielkiej Brytanii, potem zaś także na ziemiach polskich. Tego typu praktyka, oparta na kreowaniu podmiotów politycznych domagających się swej reprezentacji i widzialności w sferze publicznej, pociaga za sobą konieczność dokonania dalszych rozstrzygnięć: produkuje nowe linie podziału wewnątrz społeczeństwa i potrzebę nowych typów politycznej inkluzji (rodząc np. pytanie o to, czy robotnicy powinni być włączeni do partycypacji w instytucjach państwa jako przedstawiciele klasy, czy raczej powinni tworzyć własne instytucje obok oficjalnych) (Hayat 2013; Marzec 2016). W tym więc sensie miejscem, w którym historia pojęć spotyka się z historią społeczną, jest analiza kategorii, za pomoca których próbowano myśleć o poszczególnych grupach społecznych.

Spotkanie to nie oznacza, że historia społeczna i historia pojęć stają się sobie podobne, obie bowiem charakteryzuja inne prędkości zmian i obie są ugruntowane w odmiennych strukturach powtarzalności. Wydarzenia społeczne, choć zazwyczaj predeterminowane czynnikami pozajęzykowymi, sa jednak mediowane językowo, a także zwrotnie testują określone podłoża komunikacyjne. Pojęciowe przesunięcia w odniesieniu do dużych grup społecznych akumuluja zatem szeroki kontekst epoki, w szczególności zaś doświadczenia i dążenia poszczególnych autorów, wypowiadających się o owych grupach lub w ich imieniu. To sprawia, że pojęciowe zmiany kryja w sobie skomplikowane sieci relacji, a ich analiza jest jak ogląd historii od podszewki. W tym sensie tego typu procedury badawcze czynią historyka wrażliwym na długo trwające, powtarzalne struktury, których stałość sprawia, że ich istnienie i działanie nie zostają do końca uświadomione sobie przez 
określonych aktorów, a jednak determinują one pewne dyskursy i mają wpływ na politykę (Koselleck 1998; Koselleck 2001; Koselleck 2004, 108).

W procesie pojęciowej zmiany przekształceniom podlegają nie tylko zasoby języka, ale także warunki materialne, w ramach których pojęcia są formowane i do których się odnosza. Nie bez powodu wszakże przed dziewiętnastym wiekiem w polskiej, ale i europejskiej myśli politycznej pojęcia, za pomocą których konceptualizowano klasę robotniczą - czyli przede wszystkim ludzi pracujących w warsztatach rzemieślniczych, później także w manufakturach - podtrzymywały status quo. Wszak w ściśle zdefiniowanej strukturze stanowej miasta były niemal nieobecne, a funkcjonujące w ich obrębie rzemiosło było zorganizowane w dziedziczną i zhierarchizowaną strukturę cechowa, która naśladowała drabinę feudalną. Przezwyciężenie uciążliwej zależności, przypominającej patriarchalne stosunki rodzinne, w zakładach rzemieślniczych dokonało się dopiero w dziewiętnastym wieku.

Proces ten najwcześniej dał o sobie znać we Francji. W efekcie rewolucji już w 1791 roku prawnie zakazano istnienia wszelkiego typu korporacyjnych związków pracowniczych, łączących szczeble tradycyjnej hierarchii (od mistrzów do terminatorów). W tym samym czasie pojawiać zaczęły się nowe określenia odnoszące się do osób pracujących fizycznie. Antyrewolucyjny Extrait d'un dictionnaire inutile odnotowuje już w 1790 roku, odwołujące się do tradycji antycznej, pojęcie prolétaire jako przeciwstawne dla bourgeois (Koselleck, Spree, Steinmetz 2001, 498). W pierwszych dekadach dziewiętnastego wieku francuskie słowniki zawierały zarówno pojęcie ouvrier w znaczeniu osoby, która pracuje własnymi rękami (Marguery 1818, 371; Madelaine 1823, 415; Roquefort-Flaméricourt 1829, 151), jak również proletaire, odnoszące się bądź to do najniższej klasy obywateli w starożytnym Rzymie (Madelaine 1823, 476; Roquefort-Flaméricourt 1829, 275), bądź po prostu do „zwykłych ludzi” (Marguery 1818, 421).

$\mathrm{Na}$ przełomie osiemnastego i dziewiętnastego wieku do szeregu istotnych zmian doszło także w brytyjskiej organizacji pracy i w sposobach mówienia czy myślenia o samych pracownikach. Jak twierdzi E.P. Thompson, u progu dziewiętnastego stulecia przedstawiciele właściwie wszystkich kręgów politycznych w Wielkiej Brytanii zgodni byli co do tego, że siła pary i maszyn tworzy zupełnie nową klasę robotniczą, choć oczywiście różnił ich zasadniczo stosunek do tej klasy. Obserwatorzy z wyższych warstw społecznych postrzegali każda manufakturę już nie jako jeden ze szczebli stabilnej hierarchii społecznej, ale jako potencjalne 
zarzewie buntu. W tym więc sensie wszystkie maszyny wytwarzały nie tylko towary, ale i rewolucję społeczną (Thompson 1968, 189-192). Co jednak interesujące, pojęcie proletariusza nie pojawia się jeszcze w słowniku Williama Perry’ego z 1800 roku, definiuje on jedynie słowo worker jako osobę, która pracuje (Perry 1800, 556). Z kolei w słowniku z roku 1834 oprócz słowa worker pojawiają się również wyrazy takie jak proletarian (w znaczeniu: przeciętny, nędzny, wstrętny, pospolity) oraz a proletary (człowiek pospolity, z warstwy niższej) (Johnson et al. 1834, 729), pozostające bez wyraźnego związku z klasą robotniczą i światem pracy jako takim.

W kontekście polskim tego typu procesy zachodziły później, a samo pojęcie proletariat pojawiło się, o czym poniżej, jako rezultat obserwacji francuskiej rzeczywistości społeczno-politycznej, a nie analizy rodzimych stosunków. W polszczyźnie na przełomie osiemnastego i dziewiętnastego wieku istniały już pojęcia robotników, wyrobników, rzemieślników i przemysłu, miały jednak zupełnie inne, wyraźnie przednowoczesne znaczenia. Odpowiednio, według słownika z 1812 roku, robotnicy to „roboczy ludzie”, „pańszczyznę odbywający”, „czyniciele”, „sprawcy”, „działający” (Linde 1812, 36-37). Wyrobnicy z kolei oznaczali ludzi pozbawionych stałego miejsca pracy i migrujących w poszukiwaniu krótkoterminowego zatrudnienia, rzemieślnicy natomiast wpisywali się w istniejące struktury stanowe (Assorodobraj 1966, 11). Co warte podkreślenia, władzom zaborczym zależało na utrzymaniu przednowoczesnego porządku symbolicznego, stąd też np. w odniesieniu do Galicji urzędowe statystyki austriackie w 1804 roku konsekwentnie definiowały wszystkich pracowników najemnych w kategoriach stanowych (Buszko 1986, 17). Przemysł u progu dziewiętnastego wieku oznaczał z kolei po prostu organizację pracy. Oświeceniowe rozważania nad tak pojmowanym przemysłem, zmierzające do pozytywnego waloryzowania miast, wiązały się natomiast z traktowaniem ich mieszkańców jako jedności. Jeśli zaś oświeceniowi autorzy dostrzegali możliwość zaistnienia sprzecznych interesów wewnątrz ośrodków miejskich, czynili to zazwyczaj wzdłuż osi narodowościowej, np. upadły polski „przemysł” zestawiali z zaradnością żydowskich kupców (Surowiecki 1886, 177-188). Dlatego też samo wprowadzenie kategorii klasy czy proletariatu do języka polityki otwierało horyzont oczekiwań, w którego starych ramach coraz trudniejsze stawało się dalsze reprodukowanie przestrzeni doświadczeń. Nowe problemy nie dawały się już rozwiązywać przy użyciu dawnych metod i kategorii, a modernizujące się instrumentarium pojęciowe stanowiło wyzwanie dla istniejących relacji władzy i hierarchii społecznych. 


\section{Kapłani nowego życia czy grabarze cnoty? (1832-1846)}

Przekroczenie progu doświadczenia wiąże się z rozpisaniem na nowo politycznych tożsamości i z początkiem istnienia nowoczesnych ideologii politycznych, w tym socjalizmu. Socjalizm w swych początkach nastawiony był nie tyle na mobilizację jego zwolenników, ile na krytyczną analizę zjawisk społecznych, stąd refleksja pierwszych adeptów tego nurtu nie była zorientowana na robotników. Socjalizm u zarania był przede wszystkim intelektualnym wysiłkiem, podjętym w celu rekonstrukcji świata zrujnowanego po doświadczeniach rewolucji, wojen i przemocy. Prąd ten, biorąc w obronę szeroko pojętą „klasę industrialną”, stawał tym samym w kontrze do rządów restauracji, faworyzującej bezczynnych rentierów. Jednak w drugim ćwierćwieczu dziewiętnastego wieku (1825-1850) na francuskiej lewicy stopniowo dawał się odnotować proces dostrzegania w robotnikach znaczącej siły społecznej, co pociagnęło za sobą powolną reorientację lewicowej polityki na obronę interesów tej grupy (Bouchet et al. 2015, 8-10). Pojęcia takie jak wyzysk, klasa robotnicza czy proletariat, które już wkrótce stały się kluczowe w socjalistycznej narracji, spopularyzowało ukazujące się od 1824 roku saintsimonistyczne pismo Le Globe (Bellet 2015, 52). Z kolei w latach 1830-1834, na bazie obserwacji m.in. powstania lyońskich tkaczy, zaczęto postrzegać robotników jako odrębną klasę społeczną, która wykonuje użyteczną pracę, lecz przez nową arystokrację (bourgeois) jest utrzymywana w stanie zbliżonym do poddaństwa (Sewell 1994, 200; Sewell 2007, 199, 248). Wszystkie te pojęciowe zmiany, z uwagi na transnarodowy wymiar procesu formowania się politycznej nowoczesności, wywierały trudny do przecenienia wpływ na polskie myślenie polityczne.

Zwrot, który w drugiej ćwierci dziewiętnastego stulecia miał miejsce w łonie francuskiej lewicy, nie uszedł uwadze polskich emigrantów, którzy znaleźli się we Francji w efekcie klęski powstania listopadowego. Wbrew często powtarzanej w polskiej historiografii tezie zjawisko Wielkiej Emigracji nie było prawdopodobnie fenomenem unikalnym w skali Europy (Goddeeris 2013, 23-24). Niemniej z uwagi na skalę transferu pojęć z francuszczyzny jego rola jest trudna do przecenienia, jeśli chodzi o akcelerację pojęciowej zmiany w obrębie polskiego myślenia politycznego. Transfer ów nie odbywał się w próżni i nie był bezrefleksyjny - polscy radykałowie, domagając się odzyskania niepodległości, nie przejmowali pacyfistycznych intuicji obecnych w myśleniu zdecydowanej większości francuskich socjalistów lat trzydziestych. Nie bez znaczenia dla przebiegu tych transferów pozostawał również silny wpływ romantyzmu na formowanie się ówczesnych idei 
politycznych. Romantyzm wywarł znaczny wpływ na francuskie nurty socjalistyczne (Chaïbi 2014), ale to w kontekście polskim odnotować można najdłużej trwające i najbardziej wpływowe mutacje myślenia romantycznego. Wynikało to z jego użyteczności w zakresie sugestywnego i emocjonalnego ukazywania rozbiorów. Demokratyzacyjny potencjał, niewątpliwie obecny w myśleniu romantycznym, wiązał się jednak ze specyficznym, ambiwalentnym podejściem do nowoczesności (który trafnie określić można jako jej „spirytualizacje”) (Trencsenyi et al. 2016). Prymat kategorii duchowych nad empirycznymi wśród przedstawicieli ówczesnej lewicy wiązał się często z przekonaniem, że to lud wiejski przechowuje w nietkniętej jakoby formie wartości moralne i narodowe. W tym sensie emancypacja tej warstwy (czy to przez jej „uszlachcenie”, czy przez przełamanie hegemonii szlachty drogą krwawej rewolucji), oznaczająca odrodzenie „ducha” czy „życia narodowego”, postrzegana była jako warunek konieczny do wywalczenia niepodległości. Takie myślenie utrwalało postrzeganie konfliktów społecznych w kategoriach antagonizmu chłopstwa i szlachty. Z tego powodu związani z nowoczesnym przemysłem robotnicy jawili się znacznej części teoretyków lewicowych i demokratycznych lat trzydziestych i czterdziestych dziewiętnastego wieku jako obcy. Wynikało to z faktu, że skala i tempo industrializacji na ziemiach polskich były zupełnie inne niż w Europie Zachodniej. Co więcej, miejscy robotnicy jako podmiot polityczny stawali w poprzek utartych schematów myślenia i użytecznych - z punktu widzenia narodowo-romantycznej wizji świata - opowieści.

Konceptualizacja nowoczesnej klasy robotniczej w samych swych początkach, czyli tuż po przybyciu uczestników powstania listopadowego do Francji, odbywała się za pomocą słów zaczerpniętych wprost z francuszczyzny. Świadczyć o tym może korespondencja z tego właśnie okresu, w której funkcjonowało pojęcie ouvrier (List z [b. d. i m.] 1832 [nadawca nieczytelny], 11). Niemniej właśnie dzięki bezpośredniemu kontaktowi z robotnikami przemysłowymi, a także z francuską myślą polityczna, pojęcie proletariatu bardzo wcześnie pojawiło się w polszczyźnie. Moment jego wkroczenia do rodzimego języka politycznego można wskazać bardzo precyzyjnie: miało to miejsce w styczniu 1834 roku na łamach pisma Prayyszłość, za sprawą Adama Gurowskiego. Henryk Głębocki w swej obszernej monografii na temat Gurowskiego sformułował tezę, że publicysta zaczerpnął to pojęcie od Jeana Sismondiego (Głębocki 2012, 324). Jest to prawdopodobne, gdyż Sismondi stosował pojęcie proletariatu w ramach analiz prowadzonych w polu ekonomii politycznej (Lutfalla 1965, 665; Lovell 2015, 73-75). Także Gurowski starał się używać tego pojęcia nie tylko w odniesieniu 
do kategorii moralnych (oburzając się na proletariacką nędzę), ale też próbując formułować konkretne rozwiązania:

Pracownikom świat należeć będzie. Pracownik niebędzie wtenczas proletarjuszem potyranym jak dziś, ale kapłanem nowego życia. Otóż już dziś przez ich usta prawda się objawia. Z ich czynów prostych, nie skomplikowanych, wychodzi organizacja. Bo prawa ludzkości, jak nie są fikcją tak nie są same w sobie powikłane [p.o.] (Gurowski 1834, 23).

Co interesujące, Gurowski w cytowanym fragmencie użył pojęcia „pracownik” nie jako synonimu „proletarjusza”, lecz jako kategorii bardziej ogólnej, podczas gdy wspomniany „proletarjusz” oznaczał tu pracownika w określonym położeniu społecznym. Ponadto autor przytoczonych słów wprowadził pojęcie „proletarjusz” w formie zbliżonej do jej współczesnego kształtu. Ten sposób zapisu nie był czymś typowym w jego czasach.

Bardziej zniekształcony zapis pojęcia proletariatu pojawił się m.in. w o kilka miesięcy późniejszym Akcie wiary Ogótu Polaków w Londynie. Ogół ten miał być zbiorczym ciałem wyrażającym interesy i dążenia polskich emigrantów mieszkających w tym mieście, jednak 29 sierpnia 1834 roku lewicowa grupa w ramach Ogółu (licząca 64 osoby) ogłosiła rozłam, natomiast trzy dni później, 1 września 1834 roku, za sprawą aktywności tych osób przyjęty został właśnie wspomniały akt. Deklarowano w nim dążenie do osiagnięcia równości społecznej, „do owej równości demokratyczno-socjalnej, nie znającej pana obok proletera” (Akt wiary Ogólu Polakón w Londynie 1962, 188). W podobnie zniekształconej formie pojęcia tego używały, także funkcjonujące na gruncie brytyjskim, Gromady Ludu Polskiego. Jeden z głównych ideologów tej grupy, Stanisław Worcell w swym tekście O własności, w którym analizował on własność pod kątem historycznych uwarunkowań jej powstania, wspomniał o proletariacie: „Proletarze i mieszczaństwo we Francji [...] niczem nie sa innem jak skrzypem rozpadającego się dzisiejszego społeczeńskiego porządku, w obec zbliżającej się nowej formy własności [p.o.]" (Worcell 1854, 69). W tej kwestii Worcell, w sposób typowy dla socjalizmu w latach trzydziestych dziewiętnastego wieku, uznał samo istnienie proletariatu nie za przejaw określonych warunków rozwoju społeczno-ekonomicznego, lecz za objaw kryzysu. Jednocześnie jednak w manifestach Gromad odnaleźć można zupełnie inne pojęcia służące do opisu klasy robotniczej: „Za jedno słówko wyznania ludowej we wszechwładztwo wiary, zyszcze niegdyś uprzywilejowany równy z wyrobnikiem, z rolnikiem, w narodowem wszechwładztwie udział [p.o.]" (Lud Polski Gromad Grudziażi Humań o Centralizacji Emigracyjnej 
do Emigracji Polskiej 1854, 132). Innych wreszcie przykładów stosowania pojęcia „proletariat” w formie zniekształconej dostarcza publicystyka pisma Zjednoczenie, wydawanego przez Gminę Havre Zjednoczenia Emigracji Polskiej. Komentując rewolucję francuską w Prospekcie do Zjednoczenia, pisano: „Jakoż widzimy, do czego ta rewolucja przyprowadziła. Z arystokracji rodu zrobiła się arystokracja pieniędzy, z poddanych zrobili się proleterowie, wyrobnicy, daleko więcej od pierwszych nieszczesśliwsi [p.o.]" (Prospekt do Zjednoczenia 1841, 3). Widać więc, że słowo proletariat w omawianym okresie występowało w kilku formach zapisu, co świadczy o tym, że było ono traktowane jako nowe, a przez to używano go intuicyjnie. Pojęcie to stosowane było przede wszystkim w kontekście krytyki zachodnioeuropejskiego industrializmu. W przypadku odniesień do ziem polskich zamieniano je np. na przywołane powyżej pojęcie wyrobnika, traktując fenomen proletariatu jako nieobecny w polskiej strukturze społeczno-gospodarczej.

Wyrobnik to jednak nie jedyna kategoria używana podczas analiz sytuacji na ziemiach polskich. Środowiska polityczne, dostrzegające w omawianym okresie problem ośrodków miejskich, były stosunkowo nieliczne. Przekroczyły one jednak - obecne choćby u cytowanego wcześniej Wawrzyńca Surowieckiego - przekonanie o swoistej jednolitości mieszkańców miast. Przykładem tej tendencji jest tekst opublikowany na łamach redagowanego przez Szymona Konarskiego i Jana Czyńskiego czasopisma Pótnoc w 1835 roku. Jak przypuszcza Adam Gałkowski, w piśmie tym problematyką wsi prawdopodobnie zajmować miał się pierwszy z wymienionych redaktorów, kwestia miejska zaś pozostawać miała w gestii Czyńskiego (Gałkowski 2004, 73-74). Autor wspomnianego tekstu przedstawiający się jako niemiecki republikanin Józef Mainzer - chce przemówić

\footnotetext{
za tą pracowita klassą rzemieślników, osadników miejskich których liczba w samej polsce przeszło dwa miliony wynosi. Są oni szczęśliwsi od chłopów, ale nie sa szczęśliwi. I oni w pocie czoła pracują na panów; z tym dodatkiem że szlachta nienawidząca rzemiosł nimi pogardza, że księża ich jako protestantów prześladuja [p.o.] (Do redakcyi Pótnocy 1835, 11).
}

W innych numerach autorzy publikujący na łamach tego czasopisma ukazywali ówczesnych robotników w podobny sposób. Łącząc bogactwo kraju z rozwojem miast, anonimowy publicysta Pólnocy pisał: 
Szlachcie żyjącej potem chłopów zbywało jeszcze na potrzebach i wygodach które rodzi praca połączona z przemysłem. Dumna a miłująca próżniactwo otworzyła wstęp dla obcych. Tłumami nadbiegali przemyślni i pracowici robotnicy z Germanii. Powstały miasta, obudził się przemysł, pomnożyły się warsztaty [...] Czyliż szlachta podała rękę bratnią tym szacownym pracownikom. Nie. Ci co deptali chłopa pogardzili rzemieślnikiem. Od tysiąca lat osiadłym, ponoszącym ciężary, żyjącym z przemysłu i pracy, wspólnikom nieszczęść i chwały, odmawiali imienia polaka. Okryli pogardą rzemiosła [p.o.] (Polacy których našywaja niemcami 1835, 34).

Również w swych powieściach Czyński wielokrotnie umieszczał wątki związane z szeroko pojętą klasą robotnicza: wyrobnicy mimo godziny policyjnej „czynili wyprawy na kontrabandy”, a żydowski fabrykant płacił zatrudnionym robotnikom wyższą dniówkę niż polski szlachcic pracującym dla niego chłopom za miesiąc pracy (Czyński 1907, 82-83, 112 113). Generalnie rzecz biorąc, główną intencją tego typu narracji było uzasadnienie istotności kwestii miejskiej, która była spychana na margines przez dużą część publicystów i środowisk Wielkiej Emigracji. W kwestii tej dostrzegano już jednak aspekty ekonomiczne oraz wynikające z nich nierówności społeczne istniejące wśród mieszkańców miast.

Z cała pewnością tematyka ta lekceważona była przez przedstawicieli najważniejszego lewicowego ugrupowania działającego w kręgach Wielkiej Emigracji, czyli Towarzystwa Demokratycznego Polskiego. Znajduje to odzwierciedlenie nie tylko w pojedynczych wypowiedziach publicystycznych, ale także w oficjalnych dokumentach TDP. Obydwa manifesty wydane przez to ugrupowanie w zasadzie nie poruszaja problematyki robotniczej, eksponują za to głównie konflikt na linii chłopi-szlachta (Akt założenia Towarzystwa Demokratycznego Polskiego 1954; Manifest Towarzystwa Demokratycznego Polskiego 1954). Innym świadectwem przemawiającym za niedostrzeganiem problematyki robotniczej przez prominentnych ideologów TDP jest korespondencja, stanowiąca pozostałość po niezrealizowanym projekcie słownika pojęć politycznych, w którym omówione byłyby one z perspektywy demokratycznej. Wśród kilkudziesięciu haseł, które zaproponowano wstępnie, nie znalazło się żadne pojęcie odnoszące się do klasy robotniczej (List Wiktora Heltmana do Jana Nepomucena Janowskiego 10 lutego 1839, 24).

Również w ramach dyskusji nad tzw. Kwestya przedwstephna, podczas której wszystkie sekcje TDP miały możliwość nadsyłania swoich głosów publikowanych następnie w Okólnikach Towarzystwa, dostrzec można tendencje do ignorowania problemu miejskiego, a wręcz negatywnego waloryzowania ośrodków miejskich jako takich. Wprowadzając w tę Kwestye, Centralizacja TDP pisała:

Uzupełniając obraz przedstawiający różnicę stanów w społeczeństwie polskiem, załączamy tu jeszcze uwagi nad stanem miejskim, którego część największa do nieuprzywilejowanej klasy, policzoną być może. Miasta albowiem nasze, oprócz 
nie wielkiej liczby znaczniejszych, zapełnione są mieszkańcami trudniącymi się jak lud wiejski uprawą roli. Właściwi mieszczanie, fabrykom, rzemiosłom, handlowi oddani w małej są liczbie [p.o.] (Kwestya przedwstepna 1838, 152).

Sekcya Poiters podnosiła przede wszystkim problem obcości miast (jako ośrodków zamieszkanych głównie przez ludność niemiecką i żydowska), ale także przestrzegała przed niebezpieczeństwem wytworzenia się w miastach ,arystokracji pieniężnej” (Kwestya pržedwstepna 1838, 152-153). W nieco innym tonie wypowiedziała się Sekcya Clermont: „Monarchizm, z natury swojej na nierówności, na przywilejach, na różnicy stanów opierający się [...] dał początek klasie mieszczan”, dodając jednak: „Za rewolucyi Kościuszki, lud to warszawski, krakowski, wileński, wojska opiekunów naszych pobił i wygnał, a naczelnych menerów Targowicy przykładnie ukarał”. Sekcya Angers z kolei wskazywała, że „klasę mieszczan” podzielić trzeba na „dwie klasy: zamożną i uboga”. „Drugą tę klasę składają rzemieślnicy wszelkich rzemiosł i mniejsi handlarze [p.o.]” (Kwestya pržedwstepna 1838, 154). Jeden z przedstawicieli Sekcyi Clermont zwrócił zaś uwage na kompozycję stanu mieszczańskiego, pisząc: „Klasa wyrobników, służących, najuboższych rzemieślników i t.p. nader liczna, jeżeli do niej biednych nędzarzy, bo z głodu umierających żydów dodamy, jest pod względem materyalnym tak jak chłopi nieszczęśliwa [p.o.]” (Kwestya pręedwstępna 1838, 157). Na podstawie przytoczonych przykładów wysnuć można tezę, że problem ubogich, pracujących mieszkańców miast w latach trzydziestych dziewiętnastego wieku był używany przez przedstawicieli TDP przede wszystkim jako argument służący udowodnieniu fatalnego wpływu szlachty na historyczna trajektorię rozwoju Polski. Nie stanowił on natomiast odrębnego zagadnienia teoretycznego.

Co interesujące, TDP z oporem przyjmowało odmienną pojęciowość w tej sferze nawet w sytuacji, gdy przedstawiciele ugrupowania czytali pisma teoretyków, którzy wprost rozważali problem emancypacji klasy robotniczej. Na łamach wydawanego przez TDP czasopisma analizowano np. działalność Pierre’a Leroux - człowieka, który wprowadził pojęcie socialisme do języka francuskiego i zaangażował grupy robotnicze w działania w ramach republikańskiego Société des droits de l'homme (Towarzystwa Praw Człowieka) (Żaliński 1976, 40-41). Omawiając jego poglądy, Leonard Rettel, publicysta TDP pominą aspekt robotniczy koncepcji Leroux. W części swego tekstu z 1840 roku, która jest poświęcona zagadnieniu własności w ujęciu francuskiego myśliciela, Rettel zastosował asymetryczne pojęcia dziedzica i niewolnika zamiast kategorii bardziej adekwatnych 
do określonego stanu stosunków społecznych (Rettel 1840, 332). Ten sam autor zresztą dwa lata później w jednym ze swych tekstów użył pojęcia „klassa robocza [p.o.]” w odniesieniu do chłopów (Rettel 1842, 186). Przykład tego publicysty, ukazujący kreatywny charakter transferu francuskich pojęć politycznych do polszczyzny, nie jest bynajmniej odosobniony.

Funkcjonowali bowiem w kręgach emigracyjnych publicyści, którzy potrafili blisko współpracować z twórcami pierwszych ruchów robotniczych, a jednocześnie pozostawać pojęciowymi konserwatystami, stosującymi stanowe kategorie do opisu modernizującego się społeczeństwa. Do grona takich osób, cechujących się wręcz negatywnym nastawieniem do miast jako takich, zalicza się bez wattpienia ważny współpracownik Etienne’a Cabeta Ludwik Królikowski. Był on zaangażowany w utworzony dzięki wieloletniej aktywności Cabeta ruch ikaryjski, reprezentujący odmianę komunizmu, która zdobyła pewna popularność wśród robotników, przede wszystkim Paryża i Lyonu (Fourn 2014, 101, 119, 132). Królikowski pozostawał jednak względnie niezależny, jeśli chodzi o myślenie polityczne do tego stopnia, że prawdopodobnie jeden z programowych tekstów ruchu ikaryjskiego, mimo formalnego autorstwa Cabeta, był w dużej mierze inspirowany jego pomysłami (Fourn 2014, 106). W odniesieniu do prowadzonych w niniejszym tekście rozważań, niezależność tę widać dobrze w tekście Królikowskiego z 1842 roku, w którym stwierdził on, że

\footnotetext{
Miasta wielkie, w dzisiejszym stanie, wlewają w dusze czułe jakieś posępne i grobowe uczucie; bo nie mają nic miłościwego, ani ludowego. W ulu pszczół lub w mrowisku, znajdziesz daleko więcej braterskiej społeczności, niż w dzisiejszych miastach. Dlatego ktoś nazwał je bardzo słusznie wrzodami społeczeńskimi i grobami cnoty [p.o.] (Królikowski 1842, 46-47).
}

Autor ten zbliżone poglądy wyrażał także w prywatnej korespondencji. Przykładów na tego typu polityczna niezależność od ważnych postaci francuskiej polityki w drugim ćwierćwieczu dziewiętnastego wieku można wskazać więcej.

Niezależność ta cechowała zwłaszcza tych działaczy, który w latach trzydziestych i czterdziestych pozostawali aktywni na ziemiach polskich. W swym pamiętniku Henryk Kamieński z wyraźnym entuzjazmem opisywał spiski powstające w Warszawie jako „ultrademo”: „Przepraszam za obczyznę, której nie umiem po polsku powiedzieć bez długiego omówienia. Francuzy mówią: demo, aristo, reac, zamiast: demokratyczny, arystokratyczny, reakcjonariusz" (Kamieński 1951, 64). I dodawał: 
Rzemieślnicy warszawscy spiskujący! To mi się wydawało bajecznym, niesłychanym, niespodziewanym szczęściem. Nowy pojawiał się żywioł Polski walczącej, odrętwiały od czasu Kilińskiego. Chociażby teraz zbytnia porywczością grzeszyli, chociażby nie podobna było nawet $z$ nimi się połączyć do wspólnego powstania, trzeba było się cieszyć, że się raz wzięli do działania (Kamieński 1951, 84-85).

Prawdopodobnie właśnie dzięki styczności ze środowiskiem warszawskich rzemieślników w 1844 roku na łamach wydawanego w Warszawie Præegladu Nankowego ukazał się artykuł pod wymownym tytułem Myśl o poprawie bytu klassy pracujacej, w którym pojawiło się stwierdzenie, że ubóstwo robotników to przedmiot zainteresowania „stanoznawców”. Co ciekawe, autor tekstu$^{1}$ sformułował $\mathrm{w}$ nim postulat płacy minimalnej, a także porównywał wystapienia francuskich czy pruskich robotników do działań ludu rzymskiego (Myśl o poprawie bytu klassy pracujacej 1844, 148-162).

Podsumowując tę część stwierdzić należy, że w chwili transferu do polszczyzny pojęcia służące konceptualizacji klasy robotniczej były bardzo różne zarówno jeśli chodzi o ich sposób zapisu, jak i znaczenie. Ogólna tendencja w tym okresie była taka, że refleksja nad kwestia robotniczą rozwijała się pełniej w gronie tych lewicowych publicystów, którzy z różnych powodów pozostawali poza szeregami TDP. Publicyści ci stosowali jednak dość konsekwentnie pojęcie proletariatu albo w odniesieniu do realiów angielskich czy francuskich, albo jako bardziej ogólną kategorię, oznaczającą wszelkie osoby materialnie zdegradowane. Z kolei do opisu ruchów społecznych na ziemiach polskich stosowano raczej pojęcia już w polszczyźnie ugruntowane, jak rzemieślnik czy wyrobnik. Co więcej, wśród części myślicieli daje się zaobserwować rozwój pojęć odnoszących się do problemów klasy robotniczej, np. pauperyzmu (Kamieński 1959, 360-375). Generalnie jednak trudno uznać, że w ciagu pierwszych kilkunastu lat obecności refleksji nad klasą robotniczą w polskiej myśli politycznej kwestia ta stała się centralnym punktem odniesienia dla autorów i ugrupowań proweniencji lewicowej.

\section{Kto rozwiąże zagadkę społeczną? (1846-1878)}

Wydaje się, że naszkicowana powyżej tendencja do nieufności do ośrodków miejskich jako takich zaczęła dominować w publicystyce lewicowej po rabacji galicyjskiej i po upadku

\footnotetext{
1 Tekst został podpisany inicjałami E.C. Alina Barszczewska-Krupa przypisała jego autorstwo Edwardowi Dembowskiemu, hipoteza ta jest jednak trudna do zweryfikowania (Barszczewska-Krupa 1999, 20).
} 
Wiosny Ludów. Jest to zjawisko dość paradoksalne, zważywszy że rabacja była ruchem chłopskim, który doprowadził ostatecznie do upadku zorganizowanego przez TDP powstania. Strach przed zorganizowanym ruchem chłopskim w kręgach polskich spiskowców po 1846 roku był na tyle duży, że niektóre z uczestniczek podziemnych organizacji, np. Narcyza Żmichowska, porzuciły agitację na wsiach na rzecz organizowania kursów oświatowych dla rzemieślników (Berghauzen 1974, 272-273). Mimo to strach przed antyszlachecką rewoltą nie podważał powszechnej - zwłaszcza w kołach emigracyjnych wiary w sprawczość chłopstwa, zorganizowanego pod demokratycznym sztandarem. Jednocześnie jednak zauważyć można, że przesunięcia znaczeniowe o zupełnie odwrotnym wektorze również miały miejsce $\mathrm{w}$ tym okresie i to one przygotowywały grunt pod unowocześnienie lewicowego myślenia oraz pod uznanie proletariatu za uniwersalny podmiot polityczny.

Przesunięcia te wiązały się z obserwacja ówczesnych ruchów społecznych. Nawet na ziemiach polskich w dobie Wiosny Ludów doszło do wydarzeń, których dynamika była trudno uchwytna w ramach tradycyjnej dychotomii szlachcic-chłop. We Lwowie we wrześniu 1848 roku zecerzy podjęli prawdopodobnie pierwszy w polskiej historii strajk polityczny, odmawiając składania wydawanego przez Stowarzyszenie Ziemiańskie dziennika Polska (Miller 1953, 78; Kisluk 2005, 132). 1 listopada 1848 roku, również we Lwowie, doszło do antyaustriackiej rewolty, w czasie której - według relacji z epoki - „proletariat” miał wznosić barykady (Miller 1953, 90). Wydarzenia te, z uwagą śledzone przez przedstawicieli kręgów lewicowo-demokratycznych, powodowały istotne zmiany w ramach politycznego myślenia.

$\mathrm{Na}$ przełomie lat czterdziestych i pięćdziesiątych dziewiętnastego wieku zmiany te dotyczyły przede wszystkim coraz wyraźniejszego dostrzegania znaczenia pracy i związanej z nią problematyki. Jednym z przejawów tej tendencji był tekst Socjalność, w którym stwierdzano, że źródłem własności socjalnej jest praca wytwórcza, a własności nadanej koncesja (Podolecki 1955a, 177). Pozytywna waloryzacja pracy jako takiej i potraktowanie jej jako źródła wszelkiej własności wpływało także na konkretne inicjatywy podejmowane przez środowiska polskiej lewicy. W kręgach emigracyjnych najistotniejszym bodaj przykładem próby zbudowania struktury organizacyjnej w oparciu o identyfikację nie ideową, ale właśnie pracowniczą było powołanie Zjednoczenia Polskich Pracowników 4 marca 1866 roku. Nie był to związek zawodowy, lecz stowarzyszenie samopomocowe udzielające jego 
członkom wsparcia „w czasie choroby, braku pracy lub ciężkiej przygody” (Zjednocz̧enie Polskich Pracowników 1866, 4). ZPP powstało w dużej mierze z inspiracji wspomnianego już Czyńskiego, a rozwój tej organizacji był na tyle pomyślny, że po kilku miesiącach była ona w stanie zorganizować własną czytelnię oraz zapewnić swym członkom opiekę zdrowotną. Czyński tłumaczył, że pojęcie „pracownik”, pojawiające się w nazwie tej organizacji, obejmuje zarówno pracowników umysłowych, jak i robotników (Gałkowski 2004, 280-282). Wpisywał się on w ten sposób w pozytywistyczną narrację, wedle której ,inteligencja” była nie tyle częścią elity społecznej, ile „proletariatem umysłowym” (Molska 1962, VIII).

Przejawem pewnej politycznej samodzielności ruchu pracowniczego była także tendencja do wydawania czasopism robotniczych. We Francji pierwsze tego typu pismo, L'Echo de la Fabrique, ukazywało się w latach 1831-1834, lecz rzeczywisty dynamiczny rozwój czasopism robotniczych datuje się od lat czterdzieste dziewiętnastego wieku (Hupfel, Sheridan 2015, 113-126). Na ziemiach polskich tego typu inicjatywy zaobserwować można było nieco później. W Galicji od 1869 roku ukazywało się robotnicze pismo Rękodzielnik, zaś na rok 1872 datuje się pierwsze wydanie polskojęzycznego pisma branżowego Cq̧cionka, które było organem polskich drukarzy (Buszko 1986, 61, 70). Mimo tych niewielkich inicjatyw w szóstej czy siódmej dekadzie dziewiętnastego wieku wciąż jeszcze trudno było uznać klasę robotniczą na ziemiach polskich za autonomiczną siłę polityczna. We Francji jednak niewątpliwie już w czasie Wiosny Ludów klasa ta ugruntowała swoją autonomiczność w polu politycznym.

Autonomiczność tę do pewnego stopnia zaobserwować można, analizując zasób słownikowy z tego okresu. Słowniki co prawda w różnym stopniu, zazwyczaj z pewnym opóźnieniem, reaguja na przemiany języka politycznego, jednak w okresie kilkunastu lat po Wiośnie Ludów w tego typu opracowaniach zaczęło pojawiać się słowo „proletariat”, definiowane coraz częściej w wyraźnie nowoczesnym sensie. W kręgach anglojęzycznych słowniki z lat sześćdziesiątych i siedemdziesiątych, w przeciwieństwie do wcześniejszych opracowań, zawierały hasło „proletariat”, choć ich autorzy często podkreślali obce pochodzenie tego słowa. W 1862 roku Peter Bullions wskazywał, że proletarus to termin pochodzenia łacińskiego, oznaczający jedną z uboższych klas rzymskiego społeczeństwa (Bullions 1862, 767). Z kolei autor anglojęzycznego słownika z 1873 roku podkreślał, że słowo proletaire jest pochodzenia francuskiego i oznacza osobę z pospolitego tłumu, zwykłego, często nędznego człowieka (Longmiur 1873, 358). W kontekście francuskim 
słownik synonimów z 1858 roku podaje aż siedem wyrazów bliskoznacznych terminu ouvrier (Lafaye 1858, 1090). W innym słownikowym opracowaniu z 1863 roku pojawiło się już słowo „proletariat” rozumiane jako klasa proletariuszy lub proletariat nowoczesny. W tym samym słowniku uwagę zwraca rozbudowana, dwuczłonowa definicja „proletariusza”, w której obok typowego odwołania do starożytnego Rzymu pojawiło się także stwierdzenie, że jest to klasa ludzi typowa dla społeczeństw nowoczesnych, nieposiadająca własności i pracująca w miastach (Dictionnaire de la langue française 1863, 1344). Wreszcie w polskojęzycznym słowniku z 1861 roku umieszczono zarówno pojęcie „proletarjat” (rozumiane jako „stan proletarjuszów”), jak i definicję słowa „proletarjusz”, która zawierała jednak jedynie odwołanie do Rzymian nieposiadających „osiadłości” (Zdanowicz 1861, 1203).

Jak wskazano, słowniki reaguja zazwyczaj z pewnym opóźnieniem na zaszłe już zmiany pojęciowe. $\mathrm{Na}$ bazie doświadczeń Wiosny Ludów w obrębie polskiego myślenia lewicowego formułowano już w 1849 roku refleksje, w których stosowano pojęcie proletariatu w wyraźnie unowocześnionym sensie. Różne określenia klasy robotniczej wielokrotnie pojawiły się np. w książce Edmunda Chojeckiego Rewolucjoniśsi $i$ stronnictwa wsteczne. Użył on pojęcia „proletarjat” aż ośmiokrotnie, „wyrobnik” kilkanaście razy (w tym jako „ruch wyrobniczy” lub „masy wyrobnicze”), wielokrotnie posłużył się również pojęciem „robotnik”. Autor dostrzegał antagonistyczny charakter relacji kapitału i pracy, pisząc: „kapitalista puszczał się na olbrzymie przedsięwzięcia, zakładał ogromne rękodzielnie, sprowadzał massy wyrobników, gdy mu zabrakło własnych zasobów czerpał obficie w urojonej skrzyni kredytu, nareście bankrutował i tłumy nędzarzy o głodzie na bruk wypędzal [p.o.]" (Chojecki 1849, 112). Jako jeden z pierwszych na gruncie polskim Chojecki opisał pauperyzm środowisk robotniczych (stosował samo pojęcie pauperyzmu w swojej analizie), odmalowując obraz

całych pokoleń żyjących w zatęchłych podziemiach, bladych, wychudłych, piętnaście godzin dziennie wprzężonych do pracy, śpiących na błotnistych barłogach, pożywających nędzną strawę raz na dzień zgotowana, istot na podobieństwo Boga stworzonych a zamienionych nędzą w martwe kółka maszyny [p.o.] (Chojecki 1849, 114).

Dostrzegając, że rewolucja jest „jednym z najgwałtowniejszych ruchów dziejowych”, był Chojecki przekonany, że Francja jest najbliżej rozwiązania problemu pauperyzacji klasy robotniczej, czyli owej palącej „zagadki społecznej” (Chojecki 1849, 236). Z uwagi na typ 
przeprowadzonej analizy, a także na stosowaną w niej pojęciowość, tekst ten jest czymś absolutnie wyjątkowym na tle dominujących w epoce dyskursów polskiej lewicy.

Po upadku Wiosny Ludów w TDP, które w latach 1846-1848 skupiło w swych szeregach zdecydowaną większość przedstawicieli emigracyjnych kręgów lewicowych, na pierwszy plan wysunęła się idea odrębnej drogi rozwojowej Polski. Tendencję tę obrazuje odezwa Centralizacji TDP z 1849 roku, w której stwierdzano:

u nas rozwój nawet rewolucyi jest więcej uproszczony jak gdziekolwiek. Kwestye bowiem społeczne, które z jednej strony szerzą wprawdzie żar rewolucyi i utrzymuja żywotność jej w całej Europie, lecz z drugiej strony pochłaniając całą działalność mas, wikłaja pod pewnym względem i opóźniają wszędzie jej pochód polityczny - kwestye te naszej narodowej insurekcji wikłać nie będa. W Polsce, w kraju rolniczym, zadania społeczne reasumują się dziś głównie do zmiany stosunków pomiędzy klasą wydziedziczoną dotąd a klasą posiadających - słowem, u nas, głównem w tej chwili zadaniem społecznem jest usamowolnienie i uwłaszczenie ludu [p.o.] (Centralizacya Towaraystwa Demokratycznego Polskiego do ogótu towarzystwa 1849, 2).

W tym więc sensie przygotowanie materialnej podstawy pod zmianę stosunków politycznych miało być łatwiejsze na gruncie polskim właśnie z uwagi na rolniczą strukturę gospodarki.

Tendencja ta doprowadziła do wtórnego wpisania wszelkich zjawisk społecznych zachodzących na ziemiach polskich w ramy prostej dychotomii chłopi-szlachta, a także do ponownego negatywnego nacechowania ośrodków miejskich. Na łamach Demokraty Polskiego w 1846 roku pisano:

\footnotetext{
Żywioł wiejski jest dotąd przeważny u nas. [...] Mieszczanin polak, dorobiwszy się majątku wzdycha do posiadania wioski $[\ldots]$ jak na zachodzie miasto, tak u nas wieś wycisnęła piętno swoje niczem nie starte, i o tem nigdy zapominać nie wolno, bo stąd poszła różnica cywilizacyi, obyczajów, dążności i całego wewnętrznego składu społeczeństwa [p.o.] (O demokratyzmie polskim 1846, 23).
}

Gdy natomiast w publicystyce demokratów pojawiało się już pojęcie proletariatu, było ono pisane kursywą i traktowane jako neologizm. W ten sposób użył go np. Jan Kanty Podolecki w 1849 roku: „Pod lśniąca się fałszywym blaskiem skorupą zgniłego społeczeństwa ognie wulkanów hucza, potoki lawy czekają. Tam żywioł nieznany, nowy, dziki, straszny, potężny proletariat - swój najazd gotuje. Wkrótce potop Europę zaleje” (Podolecki 1955b, 123-124). Słowa te wskazują, że u progu lat pięćdziesiątych dziewiętnastego wieku proletariat 
rzeczywiście był traktowany przez ówczesną lewicę emigracyjna jako ta klasa społeczna, która może obalić porządek społeczno-polityczny w Europie Zachodniej. O ile jednak tam takie działanie rzeczywiście było konieczne, o tyle ogólnie pojęta Słowiańszczyzna wymagała raczej przywrócenia dawnej, demokratycznej jakoby organizacji społecznej. Jak słusznie dostrzegł Jerzy Jedlicki, nawet polscy rewolucjoniści w dziewiętnastym wieku mieli tendencję nie tyle do spierania się o przyszłość, co raczej do postulowania restytucji dawnych praw (Jedlicki 1988, 278).

Wśród przedstawicieli tzw. „starej demokracji”, czyli grupy, która znalazła się na emigracji zaraz po upadku powstania listopadowego i zainicjowała powstanie TDP, tego typu myślenie funkcjonowało przez wiele lat. Nawet po obserwacji doświadczeń związanych z Komuną Paryską środowisko to nie nabrało przekonania, że klasa robotnicza stanowić może istotną siłę polityczną. Co więcej, nawet u progu lat siedemdziesiątych dziewiętnastego wieku „stara demokracja” wciąż jeszcze w opisie robotników stosowała archaiczne pojęcia sprzed czterech dekad. Ilustracja tej tendencji jest jeden z listów Heltmana do Janowskiego z 1871 roku, w którym nadawca rozważał sensowność propagandy antyreligijnej wśród ludu:

między masy, których dziś potrzebujemy do zmienienia obecnego porządku politycznego i socyalnego, z myśla obalenia ich teraźniejszej wiary, iść nie można. Wyjątek stanowić może część ludności większych miast, szczególnie uwrierzy, ale oni nie tworza jeszcze dostatecznej siły [p.o.] (List Wiktora Heltmana do Jana Nepomucena Janowskiego 6 grudnia 1871, 277).

Osoby, które pojawiły się na emigracji później, np. po klęsce powstania styczniowego, posługiwały się już zupełnie innymi pojęciami w odniesieniu do robotników. Przykładem może być Ludwik Bulewski, który na emigracji znalazł się dopiero po upadku Wiosny Ludów. Uważał on, że ziemia, fabryki i warsztaty powinny należeć do tych, którzy na nich i w nich pracują, „co jedynie za pomocą stowarzyszeń wspólnej pracy (associations cooperatives) uskutecznionym być może [p.o.]" (Bulewski 1867, 67). Również Bulewski jednak podzielał ogólną koncepcję drogi odrębnej, uważając, że o ile w krajach rolniczych palącym problemem jest „kwestya włościańska”, o tyle w przemysłowych - „kwestya robotnicza [p.o]” (Bulewski 1867, 68). Sądził on mimo to, że w wyzwolonej, niepodległej Polsce konieczne jest nie tylko oparcie produkcji rolnej, ale także robotniczej i rzemieślniczej na zasadach kooperatywnych (Bulewski 1867, 105-106). Fakt, że młodsi emigranci nie mieli tendencji do niedostrzegania problematyki klasy robotniczej w swych politycznych deklaracjach, dobrze przedstawia także 
przemówienie Józefa Tokarzewicza z 1870 roku. Wychodząc z założenia dość typowego dla niektórych kręgów emigracyjnych, że transfer nowych „--izmów” do polszczyzny pozbawiony jest sensu, wskazywał on:

socyalizm tegoczesny następujące jeno lub tym podobne daje rozwiązania: Pragniecieli zbawienia ludzkości? To znieście własność. Pragniecie-li nową epokę na ziemię sprowadzić? To znieście religię. Pragniecie-li zniszczyć niewolę? To znieście małżeństwa. Pragniecie-li proletaryat z nędzy wybawić? to znieście wszelką władzę [p.o.] (Dwie bližnie ruiny, 326).

Jednocześnie Tokarzewicz akcentował, że socjalizm to ruch nowoczesny.

Okres między rabacja galicyjską a ogłoszeniem tzw. „programu brukselskiego” przedstawia się zatem, jeśli chodzi o konceptualizację klasy robotniczej, jako czas pewnego spowolnienia. Epigoński - w znaczeniu opisowym, a nie wartościującym - romantyzm na przestrzeni owych ponad trzech dekad konał nieśpiesznie. Nowe ruchy społeczne coraz śmielej wymykały się typowej dla polskich środowisk demokratycznych prostej dychotomii chłopi-szlachta, natomiast kolejne fale emigracji przywoziły ze sobą do krajów Europy Zachodniej zupełnie nowe doświadczenia. Co więcej, przybywający do Francji w roku 1848 lub w 1864 emigranci mieli inne autorytety polityczne i w efekcie coraz rzadziej odwoływali się do „nauki społecznej” pierwszych francuskich socjalistów, a coraz częściej do popierającej niepodległość Polski I Międzynarodówki (Bobińska 1954, 193-222). Nie bez znaczenia dla pojęciowej zmiany w tym okresie był również przyspieszajacy na ziemiach polskich proces industrializacji, którego rezultatem były różne formy samoorganizacji robotników. Ostatecznie jednak w omawianym w tej części artykułu okresie nie pojawiły się żadne istotniejsze przesunięcia w sferze pojęć stosowanych do opisu zarówno owych praktyk samoorganizacji, jak i samych robotników. Był to raczej czas ugruntowywania się pojęć wprowadzonych do myślenia politycznego jeszcze w latach trzydziestych i czterdziestych.

\section{Proletaryat czy stan czwarty? (1878-1892)}

Ostatnia faza procesu konceptualizacji klasy robotniczej w dziewiętnastym wieku, którą chciałbym przedstawić, obfitowała m.in. w takie wydarzenia jak powstanie I Proletariatu, zmierzch ostatniego Ludu Polskiego, poczatek wydawania czasopism pod znamiennymi 
tytułami (np. Gazeta Robotnicza, Robotnik, Walka Klas), pierwsza duża rewolta robotnicza na ziemiach polskich (tzw. bunt łódzki w 1892 roku) i wreszcie utworzenie Polskiej Partii Socjalistycznej. Był to ten moment w polskiej historii, w którym w coraz większym stopniu pojęciowa zmiana dokonywała się nie poprzez transfery z innych języków, lecz w oparciu o doświadczenia polskiej wspólnoty. Tendencję tę dobrze przedstawia tłumaczenie Manifestu Komunistycznnego na język polski z 1883 roku. Jego autor, Witold Piekarski bez żadnego dodatkowego uzasadnienia przełożył słowo proletarier na „proletaryjusz”, choć jednocześnie uznał za stosowne wyjaśnić, dlaczego burgeois przetłumaczył jako „burżua”, a nie „mieszczanin” (Marks i Engels 1883, 9). Innymi słowy, ostatnie dekady dziewiętnastego wieku nie były czasem, w którym wprowadzanie nowych idei politycznych wiązałoby się z koniecznością adaptacji całkowicie nowych słów odnoszących się do robotników. Niemniej zaszły w tym okresie dość istotne przesunięcia znaczeniowe w zakresie terminów już istniejących. Co więcej, środowiska emigracyjne w latach 1878-1892 już w minimalnym stopniu wpływały na kształtowanie się polskiego języka politycznego.

W latach siedemdziesiątych dziewiętnastego wieku zmianie uległ przede wszystkim sposób działania polskich rewolucjonistów, ponieważ spotkania na dworach szlacheckich zastapiło szukanie osobistych kontaktów z robotnikami. Jako jeden z pierwszych tego typu styl politycznego aktywizmu zainicjował Kazimierz Hildt, który już w latach 1868-1869 odwiedzał szynki i starał się rozmawiać z ich bywalcami na temat socjalizmu. Szynk dla Hildta był odpowiednikiem domu ludowego, w którym gromadzili się przedstawiciele klas ludowych. W tej właśnie przestrzeni aktywista starał się wpajać im idee zakładania związków zawodowych, kooperatyw czy kas oporu (Heryng 2007, 27-28). Wkrótce tą samą droga poszedł Ludwik Waryński, inicjator partii Proletaryat i główny twórca tzw. „programu brukselskiego". Sama nazwa tej partii wyznaczała główny kierunek działania „proletariatczyków”. Tym samym po raz pierwszy w kontekście polskim pojęcie proletariatu zostało użyte jako nazwa ugrupowania politycznego.

W programie brukselskim, napisanym w istocie w Warszawie, znaleźć można po raz pierwszy w tak jasny sposób wyłożone w polszczyźnie treści marksistowskie. Klasa robotnicza została tu potraktowana, z jednej strony, jako ofiara kapitalizmu, z drugiej zaś jako uniwersalny podmiot polityczny, reprezentujący interesy całego społeczeństwa. W programie robotnik został porównany do towaru, bo sprzedając „swą pracę wedle ogólnych praw zamiany, nie może w żaden sposób wpłynąć na jej warunki”. Robotnik zatem 
jako członek „klasy pracującej” jest ofiarą kapitalizmu. Istnieja jednak zasady socjalizmu, które są „koniecznym warunkiem pomyślnej przyszłości narodu polskiego”. Robotnicy zostali potraktowani jako reprezentanci całości społeczeństwa, ponieważ „czynny udział w walce $\mathrm{z}$ ustalonym porządkiem społecznym jest obowiązkiem każdego Polaka przenoszącego los milionów ludu polskiego nad interesy szlachecko-kapitalistycznej cząstki naszego narodu”. Kolejno, w części pt. „zasady, które wyznajemy” stwierdzono, że „praca najemna zamieniona będzie pracą zrzeszoną $w$ stowarzyszeniach fabrycznych, rzemieślniczych i rolnych”. Pod koniec programu pada otwarta deklaracja, „że dążenia nowoczesnego proletariatu znalazły ostateczny swój wyraz w Międzynarodowym Stowarzyszeniu Robotników”. Tym samym Proletaryat identyfikował się jako ugrupowanie nowoczesne (Program socjalistów polskich 1962, 55-61).

Niemniej Proletaryat jako partia, mimo silnych inspiracji marksizmem, łączył w sobie wciąż elementy charakterystyczne dla retoryki wcześniejszych (nie tylko polskich) grup lewicowych - np. pojawiające się w „zasadach” pojęcia „organizacji ludowej” czy „sił ludowych” - z kategoriami par excellence nowoczesnymi, takimi jak „kapitał” czy „robotnicy”. Do grona robotników, co znamienne, zaliczono tu także rzemieślników, generalnie traktując tę kategorię dość szeroko (Koberdowa 1981, 198-204; Koberdowa 1987, 52).

Wydaje się jednak, że stopniowo pojęcie proletariatu w dyskursie tej partii podlegało pewnemu dookreśleniu. W 1881 roku ugrupowanie wydało broszurę, której wielu autorów przypisało tytuł Kto jest robotnikiem?. Zdaniem Ireny Koberdowej ten wręcz prowokujący pojęciową zmianę tytuł nie jest prawidłowy. Badaczka ta uznała, że broszura jest przypuszczalnie zbiorem tekstów Iwana Franki, opublikowanych początkowo na łamach pisma Praca, a potem zbiorczo w broszurze O pracy. Ksiażeczka dla robotników. Autor definiowal robotnika szeroko: jest to ktoś, kto nie posiada własności i musi sprzedawać swoją siłę robocza. W tekście do robotników zaliczeni zostali także nauczyciele, lekarze, literaci, dziennikarze i technicy - ale tylko tacy, którzy działają w interesie ogółu, a nie w interesie klas uprzywilejowanych. Wreszcie twórca broszury uznał, że nie każdy, kto posiada drobną własność, jest kapitalista, zatem do grona robotników należą także chłopi i rzemieślnicy, nawet jeśli zdarzy im się zatrudnić pomocników. W omawianym okresie w podobnym tonie wypowiadali się publicyści pisma Robotnik, choć zdarzało im się odnotowywać fakt toczących się walk klasowych między czeladnikami i majstrami. Sama partia Proletaryat natomiast 2 września 1882 roku, reagując na tego typu wydarzenia, wydała ulotkę Do agentón dla 
pržedstawienia wydriatom $i$ sekcjom, w której zalecała bronić czeladników w wystąpieniach przeciwko majstrom. Z kolei na łamach pisma Walka Klas w 1885 roku pojawiały się artykuły, których autorzy sygnalizowali rozbieżność interesów rzemieślnika, chłopa i robotnika. Sam Waryński wreszcie w swej mowie obrończej z 1880 roku do proletariatu zaliczył także „inteligencję pozbawioną chleba” (Notkowski 1978, 146; Koberdowa 1981, 198-204).

Nakreślone powyżej przesunięcia znaczeniowe następowały nie tylko za sprawa sumowania określonych doświadczeń politycznych czy dyskusji wewnątrzpartyjnych, ale także w efekcie polemik z pozytywistami. W kontekście zmian w języku, odnoszących się do sposobów konceptualizacji robotników, szczególnie interesująco przedstawia się spór między Władysławem Wścieklicą a Kazimierzem Dłuskim i Witoldem Piekarskim. Wścieklica prowokacyjnie, powołując się na Kapitał, argumentował, że na ziemiach polskich nie istnieje kapitalizm w Marksowskim sensie, stąd tworzenie partii robotniczej w rodzimym kontekście porównywał do próby formowania armii bez wojska (Wścieklica 1882, 85-114). Dłuski i Piekarski w swej odpowiedzi wskazywali, że zacofanie polskiego kapitalizmu spiętrza konflikty społeczne. Byli oni także przekonani, że tworzenie partii socjalistycznej czy w ogóle bycie w awangardzie europejskiego ruchu jest możliwe również w krajach rolniczych, takich jak Węgry czy Rosja (Dłuski, Piekarski 1962, 609).

Podkreślić należy, że żadne polskie środowisko polityczne nigdy wcześniej w tak krótkim czasie nie poświęciło robotnikom tyle uwagi co Proletaryat. W efekcie znaczeniowych przesunięć w dyskursie tej partii asymetryczne pojęcia chłopa i szlachcica zostały zastapione przez dychotomię: klasy posiadające-robotnicy (miejscy i - co warte podkreślenia - wiejscy) (Odezwa Komitetu Robotniczego Partii Socjalno-Rewolucyjnej „Proletariat” 1984, 51). Co więcej, przedstawiciele Proletaryatu uznali, że „kwestia proletariacka” jest nie tylko „Zachodnia”, a przed koniecznościa jej rozwiązania - i to w okolicznościach bardziej dramatycznych niż te „Zachodnie” - stanąć muszą także społeczeństwa Europy ŚrodkowoWschodniej. Było to zdecydowane odejście od idei „drogi odrębnej”, równoznaczne z wkomponowaniem pojęcia proletariatu w pejzaż polskich walk klasowych.

W całkowicie odmienny sposób klasę robotniczą skonceptualizowano w odezwie ostatniego Ludu Polskiego, w którym wciąż znajdowały oddźwięk kategorie typowe dla stanowego rozumienia struktury społecznej. Gromady Ludu Polskiego stworzyły trwała, jak się okazało, formułę emigracyjnej organizacji politycznej, której ostatnim wcieleniem było utworzone w 1881 roku w Genewie, z inspiracji m.in. Bolesława Limanowskiego, 
Stowarzyszenie Socjalistyczne „Lud Polski”. Punktem wyjścia w wydawanej przez to ugrupowanie odezwie z sierpnia 1881 roku jest wskazanie, że szlachta „dogorywa”, natomiast burżuazja „rozciaga nową niewolę nad ludem, strąca go do znaczenia machiny i towaru, wprowadza dezorganizację społeczną” (Odezwa Stowarzyszenia Socjalistycznego „Lud Polski” 1984, 48). Wspomniany lud, którego nie zdołały zmobilizować ani środowiska z lat trzydziestych i czterdziestych, ani powstańcy styczniowi, budzi się - wedle autorów odezwy - z uśpienia. Polska zatem nie spełniła swego historycznego zadania, ale „[i]dea stanu czwartego postawi nas znowu w szeregu narodów - bojowników postępu” (Odez̧wa Stowarayszenia Socjalistycznego „Lud Polski” 1984, 48). Zdefiniowanie podmiotu politycznego według kategorii stanowych wpłynęło również na sformułowanie postulatów politycznych w podobnym tonie: zniesienie „społecznej niewoli” było przez ostatni Lud Polski rozumiane jako zniesienie klas i przywilejów stanowych, równouprawnienie płci i swoboda wyznań religijnych (Odezwa Stowarayszzenia Socjalistycznego „Lud Polski” 1984, 49). W całej programowej odezwie ani razu nie pada pojęcie klasy robotniczej, proletariatu itp.

Kilka lat później Limanowski był publicystą paryskiego pisma Pobudka, które stosowało już jednak nieco inna pojęciowość. Co prawda w tekście programowym Gminy Narodowo-Socjalistyczej, której Pobudka była organem prasowym, także nie pojawia się ani jedno bezpośrednie odniesienie do klasy robotniczej, bowiem podmiotem, który miałby kontrolować uwspólnioną własność, miał być naród (Program 1889, 1-2). Niemniej w poszczególnych artykułach kwestia robotnicza omawiana jest wielokrotnie, również w odniesieniu do sytuacji na ziemiach polskich. Autor podpisany jako K. Sierp analizował postulaty galicyjskich robotników, którzy wskazywali m.in. na zbyt małą liczbę inspektorów fabrycznych (Sierp 1889, 25). Interesująco pod kątem prowadzonych tu rozważań prezentuje się artykuł autora podpisanego jako Pankracy, który w tytule swego tekstu zastosował pojęcie „inteligentnego proletariatu”. Pankracy wskazywał, że błędem jest postrzeganie stosunków społecznych na ziemiach polskich wzdłuż osi burżuazja-proletariat, ponieważ istnieje wiele „stanów pośrednich”. W swej analizie dochodzi autor do konkluzji, że siłą rewolucyjną jest „inteligentny proletariat”, którego zadaniem jest podnoszenie poziomu wiedzy ludu, wpajanie mu „świadomości narodowej” oraz organizowanie robotników (Pankracy 1891, 1-2). Środowisko paryskiej Pobudki jest więc kolejnym przykładem daleko posuniętej ambiwalencji w sposobie pojmowania klasy robotniczej, której z cała pewnością nie traktowało ono jako 
podmiotu politycznego zdolnego do samodzielnego wywalczenia polskiej niepodległości i obalenia kapitalizmu.

Równie interesujące dwuznaczności w odniesieniu do konceptualizacji klasy robotniczej ukazuje szkic programu Polskiej Partii Socjalistycznej, sformułowany na zjeździe w Paryżu w listopadzie 1892 roku. Autorzy szkicu wyszli od konstatacji, iż przez całe stulecie, które upłynęło od trzeciego rozbioru, Polska „nie była w stanie wytworzyć ze swego łona dostatecznej siły odpornej najazdowi” (Szkic programu PPS 1984, 68). Jednak po nieudanej „rewolucji” lat 1861-1864 na ziemie polskie dotarła myśl międzynarodowego socjalizmu, „pod którego słowem ożywczym budzi się pełna gotowości do czynu, coraz bardziej świadoma swych celów i dróg Polska ludowa, którą dotychczas przy najgłośniejszym szczęku broni na próżno wywoływały przeszłe pokolenia" (Sžkic programu PPS 1984, 69). Kształtowanie się nowych sił społecznych to rezultat wyzysku kapitalistycznego, ponieważ „[w]ywłaszczanie masy włościańskiej, skoncentrowanie w miastach mas proletariatu, zdziesiątkowanie tak zwanej klasy średniej są u nas zjawiskami z życia codziennego" (Sžkic programu PPS 1984, 70). W szkicu programu PPS z 1892 roku proletariat pojawia się zatem i jako rezultat braku niepodległej Polski, i jako efekt działania kapitalizmu. Co istotne, autorzy szkicu potraktowali proletariat jako robotników wyłącznie miejskich, a dla trzech warstw społecznych, wspomnianych w cytowanym powyżej fragmencie, stosują oni zamiennie zbiorcze określenia „mas” lub „klas” pracujących. Interesująca uwaga w tekście z 1892 roku pada pod adresem wcześniejszych ugrupowań lewicowych: „Dawna demokracja nasza [...] nie potrafiła wszakże i nie była w stanie wytworzyć samodzielnej organizacji ludowej. Wina, być może, spada bardziej na ówczesne stosunki ekonomiczne kraju” (S ¿kic programu PPS 1984, 72). W tym więc sensie dostrzeżono kwestię, której nie przyswajali lewicowcy działajacy w czasie pierwszych kilkunastu lat po upadku powstania listopadowego - kapitalizm jest siła nie tylko burząca, ale także twórczą, gdyż powołuje do życia kolejną klasę, która dążyć będzie do jego obalenia. W tym celu, co podkreślono, współdziałać z proletariatem moga także „klasy przejściowe”, które jęczą „pod jarzmem gospodarki dzisiejszej”. Współdziałanie nie oznacza jednak wchodzenia „w kompromis z reakcyjnymi dążnościami klas przejściowych” (Szkic programu PPS 1984, 73-74). Generalnie rzecz ujmując, mimo stosowania przez założycieli PPS szerszych kategorii niż te, których używali socjaliści z Proletaryatu, ostatecznie i w szkicu z 1892 roku klasy pracujące, w tym i miejski proletariat, sa jednocześnie ofiarami kapitalizmu i jego grabarzami. 
Nie ma przypadku w tym, że zdecydowana większość autorów właśnie w ostatnim z analizowanych tu okresów widzi moment narodzin nowoczesnego ruchu socjalistycznego na ziemiach polskich. Rosnący wpływ marksizmu powodował, że w dyskursach krajowych ugrupowań lewicowych u schyłku dziewiętnastego wieku robotnicy zaczęli być traktowani zarówno jako ofiary realiów kapitalistycznej gospodarki (a czasem i sytuacji braku niepodległości Polski), jak również jako ci, którzy przez okoliczności dziejowe są niejako predestynowani do przekroczenia owych realiów. Co więcej, dyskursy te na robotnikach właśnie kładły akcent w ramach myśli, zgodnie z którą określona grupa społeczna (którą w latach trzydziestych i czterdziestych dla polskiej lewicy było albo chłopstwo, albo uogólniony lud-naród) stanowi część międzynarodowego ruchu klas uciskanych, walczących o emancypację. Nawet w tym nurcie jednak zwraca uwagę powracające pojęcie ludu, które zdaje się sugerować, że ta szeroka, a przez to mglista kategoria była bardzo głęboko osadzona w strukturach politycznego myślenia.

\section{Konkluzje}

Status polszczyzny w dziewiętnastym wieku był specyficzny. Nie był to język, który - jak francuski czy angielski - wywierałby przemożny wpływ na kształtowanie się pojęciowości politycznej w centrach ówczesnego świata. Z drugiej jednak strony nie był to też język, który znajdowałby się na podobnym etapie rozwoju jak np. język fiński, którego nowoczesna wersja w dziewiętnastym wieku była niemal tworzona przez tłumaczy (Stenius 2004). W tym sensie, jak wskazano, w początkach owego stulecia w polszczyźnie istniał już szereg wyrazów, za pomoca których określano ówczesnych ludzi pracy - takich jak robotnicy, wyrobnicy czy rzemieślnicy. Były to jednak pojęcia przednowoczesne i podtrzymujące status quo.

Jednak w 1832 roku, w rezultacie emigracji kilku tysięcy osób zaangażowanych w powstanie listopadowe do krajów Europy Zachodniej, transfer wielu nowoczesnych pojęć politycznych do polszczyzny odbył się stosunkowo szybko. Tam też polscy emigranci zetknęli się z nieobecnym jeszcze na ziemiach polskich nowoczesnym przemysłem i analizowali jego społeczne konsekwencje. W efekcie, transferując pojęcia służące do opisu nowoczesnej klasy robotniczej, jak proletariat czy uwrierzy, dokonywano wyłomu w myśleniu politycznym. Ostatecznie jednak w pierwszej fazie konceptualizacji zjawiska opisywane za pomocą nowej terminologii bądź to rozważane były wyłącznie w odniesieniu do problemów społecznych Europy Zachodniej, bądź pozostawały w sferze idealistycznych dociekań, 
w których „proleterów” utożsamiano z niewolnikami. W tym sensie transfer nowych pojecć otwierał pole do empirycznych i podważających status quo analiz polskiego społeczeństwa, ale w gruncie rzeczy potencjał do snucia takich rozważań nie został w pełni wykorzystany. Jak ilustruja to choćby przytaczane dyskusje na temat miast prowadzone w łonie TDP, efekt tego typu analiz był raczej statyczny, to znaczy ich autorzy w niewielkim stopniu interesowali się przemianami struktury społecznej. W tych zaś momentach, w których przejawiali oni tego typu zainteresowania, ich refleksje były niemal w całości podporządkowane kategoriom bardziej ogólnym. Ilustruje to choćby zachwyt Kamieńskiego nad zaistnieniem zorganizowanych grup rzemieślniczych, których aktywność jednak podporządkowywał on „wyższym” celom polskiego ruchu niepodległościowego. Wydaje się, że w niewielkim stopniu sytuacja ta uległa zmianie w trzydziestoleciu, które nastapiło po Wiośnie Ludów. Co prawda polscy lewicowcy, aktywni głównie na emigracji, zetknęli się z żywiołowymi walkami klasowymi, lecz utrwaliły one ich przekonanie - słabiej obecne we wcześniejszym okresie - o odrębnej drodze rozwojowej Polski. Z tego też względu problemy typowe dla nowoczesnego proletariatu uważali oni za „zagadkę społeczną” typową dla Europy Zachodniej. Niemniej, jak ilustruje to analiza zasobu słownikowego, lata sześćdziesiąte wiązały się z coraz nowocześniejszym definiowaniem „proletariatu”. Okres ten obfitował także w pierwsze próby organizacji samopomocowych związków pracowniczych, w których za pracowników uważano zarówno osoby zarabiające pracą fizyczną jak i umysłową.

Ugruntowanie się w polszczyźnie pewnych słów, które jeszcze w latach trzydziestych i czterdziestych były traktowane jako nowe, a przez to rozumiane i zapisywane intuicyjnie (stąd wspomniana wielość zapisów terminu „proletariat”), otwierało pole dla wkroczenia nowoczesnej myśli marksistowskiej. Jej adepci, poprzez krytyczny stosunek do polskiej historii, przejawiający się np. w odrzuceniu rytualnego niemal czczenia rocznic kolejnych powstań, odrzucili również przekonanie o odrębnej drodze rozwojowej, a wręcz wskazywali w dyskusjach z pozytywistami - że ziemie polskie, z powodu zacofania kapitalistycznej gospodarki, stanowia zarzewie rewolucji. Partia Proletaryat - pierwsze polskie ugrupowanie, które w tak dużym stopniu interesowało się kwestią robotniczą - przyjęła dość szerokie rozumienie terminu znajdującego się w jej nazwie. W przypadku tego środowiska konceptualizacja klasy robotniczej prowadzić miała już nie do statycznych analiz czy ostrzeżeń przed „Zachodnim” industrializmem, ale do mobilizacji. Było to powiązane ze zmianą roli odgrywanej przez myśl polityczną jako taka. O ile bowiem w pierwszej połowie 
dziewiętnastego wieku jej zasadniczym celem była krytyczna analiza rzeczywistości, o tyle później służyć ona miała również mobilizacji, kształtowaniu i regeneracji wspólnoty politycznej (Trencsenyi et al. 2016, 390).

Szereg ambiwalencji oraz splotów przednowoczesnych i nowoczesnych sposobów myślenia o robotnikach ujawnia natomiast program Stowarzyszenia Socjalistycznego „Lud Polski”, a także publicystyka Pobudki. W dokumencie „Ludu Polskiego” z 1882 roku w ogóle nie podniesiono problematyki robotniczej jako odrębnej kwestii, operowano natomiast pojęciem „stanu czwartego” i innymi, bardziej mglistymi kategoriami. Na łamach Pobudki natomiast, mimo sporej liczby doniesień o protestach robotniczych i ich analiz, za główny podmiot polityczny, który miałby wejść w posiadanie uwspólnionej własności, wciąż uznawano naród. Wreszcie w szkicu programu PPS z 1892 roku nędzę proletariatu uznano z jednej strony za rezultat kapitalizmu, z drugiej zaś - za efekt braku istnienia niepodległej Polski. Miejscy robotnicy byli tu nadal postrzegani jako jedna z klas pracujących. Wyjątkowość tej klasy polegać miała jednak na tym, że była ona zarazem wytworem i grabarzem kapitalizmu.

Uznanie klasy robotniczej za uniwersalny podmiot polityczny w kręgach polskiej lewicy było zatem procesem pełnym zawirowań i niejednoznaczności. Można jednak mieć wątpliwości, czy w obrębie polskiego myślenia politycznego proces ten kiedykolwiek uległ ostatecznemu domknięciu. Jednym z powodów tego stanu rzeczy była wyjątkowa w skali europejskiej popularność romantyzmu, wywierająca - jak wskazano - przemożny wpływ na sposoby konceptualizowania klasy robotniczej, a precyzyjniej: spowalniająca pojęciowa zmianę w tym konkretnym aspekcie. W późniejszym zaś okresie, który nie wchodzi już w obręb tego studium, wyłonienie się instytucjonalnych form masowego ruchu ludowego, nierzadko niechętnie nastawionego do zorganizowanej klasy robotniczej, także utrudniło intuicyjne traktowanie robotników jako naturalnego środowiska, w którym rozwijać się mogła polska lewica. Wydaje się, że nie była to cecha specyficznie polska. W rosyjskim kontekście u progu dwudziestego wieku działacze socjalistyczni zwracali uwagę na fakt, że pojęcia takie jak kapitalizm, świadomość klasowa czy proletariat są lepiej zakorzenione w językach łacińskich niż słowiańskich. Dlatego też ich aktywność propagandowa wiązała się z potrzebą drobiazgowego wyjaśniania tych terminów, niejednokrotnie przez posługiwanie się ogólnymi odniesieniami do chęci przywrócenia bardziej ludzkiego bytu robotnikom, którzy dotąd traktowani byli jako niewolnicy (Steinberg 1992, 146). 
Sądzić można, że - uwarunkowane specyficznymi, polskimi realiami kształtowania się nowoczesnego imaginarium politycznego - bardzo ogólne traktowanie pojęć takich jak klasa pracująca znacznie poszerzało bazę społeczną dla formowania się obszernego frontu antykapitalistycznego. Jednak dyskusja o tym, czy chłopi, robotnicy, inteligenci, bezrobotni, zubożałe drobnomieszczaństwo, lewicowi studenci itd. byliby w stanie w polskich warunkach stworzyć realny ruch rewolucyjny, została przerwana przez II wojnę światową, a zwłaszcza przez powstały w jej rezultacie reżim polityczny, który najpierw radykalnie przeformatował, a potem odgórnie zakonserwował porządek symboliczny, w tym także pojęciowość polityczna. 


\section{Wykaz literatury}

List z [b. d. i m.] 1832 [nadawca nieczytelny], Korespondencja J.N. Janowskiego, Biblioteka Jagiellońska, rkp., sygn.. 3685, t. IV.

List Wiktora Heltmana do Jana Nepomucena Janowskiego, 10 lutego 1839 r., Biblioteka Jagiellońska, rkp., sygn.. 3685, t. III.

List Wiktora Heltmana do Jana Nepomucena Janowskiego, 6 grudnia 1871 r., Biblioteka Jagiellońska, rkp., sygn.. 3685, t. III.

Dwie bliźnie ruiny (1771-1871) [Wstępny głos na publicznem polskiem zebraniu w Paryżu 18 grudnia 1870 r. miany przez J. Tokarzewicza, Biblioteka Jagiellońska, rkp., sygn.. 3685, t. III.

„Akt wiary Ogółu Polaków w Londynie”. 1962. Geneza Ludu Polskiego w Anglii. Materiały źródtowe, red. Peter Brock. Londyn: B. Świderski.

„Akt założenia Towarzystwa Demokratycznego Polskiego”. 1954. Towarzystwo

Demokratyczne Polskie: dokumenty i pisma, red. Bronisław Baczko. Warszawa: Książka i Wiedza.

„Centralizacya Towarzystwa Demokratycznego Polskiego do ogółu towarzystwa”. 1849. Demokrata Polski, cz. 1, nr 1 i 2.

Dictionnaire de la langue française. 1863. T. 2.1. Paris: Hachette.

„Do redakcyi Północy”. 1835. Pótnoc 3.

„Kwestya przedwstępna: Jakie są wewnętrzne siły społeczeństwa polskiego, uważanego pod względem politycznym i socyalnym?”. 1838. Okólniki Towaraystwa Demokratycznego Polskiego (1837/1838).

„Lud Polski Gromad Grudziąż i Humań o Centralizacji Emigracyjnej do Emigracji Polskiej”. 1854. W Lud polski w emigracji 1835-1846, red. Zenon Świętosławski. Jersey: Druk. Powszechna.

„Manifest Towarzystwa Demokratycznego Polskiego”. 1954. Towarzystwo Demokratyczne Polskie: dokumenty i pisma, red. Bronisław Baczko. Warszawa: Książka i Wiedza.

„Myśl o poprawie bytu klassy pracującej przez E.C.”. 1844. Przeglad Nankowy, R. 3, nr 32.

„O demokratyzmie polskim”. 1846. Demokrata Polski, cz. 1, nr 6.

„Odezwa Komitetu Robotniczego Partii Socjalno-Rewolucyjnej »Proletariat«”. 1984. W Powstanie II Rzeczypospolitej. Wybór dokumentów 1866-1925, red. H. Janowska, T. Jędruszczak. Warszawa: Ludowa Spółdzielnia Wydawnicza.

„Odezwa Stowarzyszenia Socjalistycznego »Lud Polski«”. 1984. W Powstanie II Rz̨eczypospolitej. Wybór dokumentów 1866-1925, red. H. Janowska, T. Jędruszczak. Warszawa: Ludowa Spółdzielnia Wydawnicza.

„Polacy których nazywają niemcami”. 1835. Pótnoc 10.

„Program”. 1889. Pobudka: czasopismo narodowo-socyalistyczne 1.

„Program socjalistów polskich”. 1962. Pierwsze pokolenie marksistów polskich. Wybór pism i materiatów źródtowych z lat 1878-1886, red. Alina Molska. Warszawa: Książka i Wiedza.

Prospekt do Zjednoczenia. 1841. 
„Szkic programu PPS”. 1984. W Powstanie II Ržeczypospolitej. Wybór dokumentów 1866-1925, red. H. Janowska, T. Jędruszczak. Warszawa: Ludowa Spółdzielnia Wydawnicza.

„Zjednoczenie Polskich Pracowników”. 1866. Niepodległość13.

Assorodobraj, Nina. 1966. Poczatki klasy robotniczej. Problem rak robocsych w przemyśle polskim epoki stanisławowskiej. Warszawa: PWN.

Baczko, Bronisław. 1959. „Henryka Kamieńskiego system filozofii społecznej. Próba interpretacji”. W Henryk Kamieński, Filozofia ekonomii materialnej ludzkiego społeczeństwa z. dodaniem mniejszych pism filozoficznych, oprac. Bronisław Baczko. Warszawa: PWN.

Barszczewska-Krupa, Alina. 1999. „W kręgu badań nad przenikaniem społecznych treści demokratycznej literatury emigracyjnej do świadomości społeczeństwa polskiego (1831-1863)". W Alina Barszczewska-Krupa, Emigracja i kraj: wokót modernizacji polskiej świadomości społecznej i narodowej 1831-1863. Lódź: Wydawn. Uniwersytetu Lódzkiego.

Berghauzen, Janusz. 1974. Ruch patriotyczny w Królestwie Polskim 1833-1850. Warszawa: PWN.

Bellet, Michel. 2015. "De l'économie politique à la politique économique. Chevalier et Le Globe". W Quand les socialistes inventaient l'avenir: presse, théories et expériences, 1825-1860, red. Thomas Bouchet, Vincent Bourdeau, Edward Castleton, Ludovic Frobert i François Jarrige. Paris: Découverte.

Bobińska, Celina. 1954. Marks i Engels a sprawy polskie do osiemdriesiatych lat XIX wieku. Warszawa: Książka i Wiedza.

Bouchet, Thomas. 2015. "Changer la société, changer la presse". W Quand les socialistes inventaient l'avenir: presse, théories et expériences, 1825-1860, red. Thomas Bouchet, Vincent Bourdeau, Edward Castleton, Ludovic Frobert i François Jarrige. Paris: Découverte.

Bulewski, Ludwik. 1867. Wolność hasłem nasæem! Lipsk: W Komisie Księgarni Pawła Rhode.

Bullions, Peter. 1862. A copious and critical Latin-English dictionary. New York: Sheldon.

Buszko, Józef. 1986. Dzieje ruchu robotnic飞ego w Galicji Zachodniej, 1848-1918. Wyd. 1. Kraków: Wydawn. Literackie.

Chaibi, Olivier. 2014. "L’internationalisation de la question sociale au cours du premier xixe siècle : de l'internationalisme des « utopistes » à l'Association internationale des travailleurs". Cabiers d'histoire. Revue d'bistoire critique [En ligne] 124.

Chojecki, Edmund. 1849. Rewolucjoniści i stronnictwa wsteczne. Paryż: Nakładem Księgarni Bebra.

Czyński, Jan. 1907. Jakobini polscy. Powieś́ z. czasón rewolucyi 1830 r. Warszawa: Nakład Gebethnera i Wolfa.

Dłuski, Kazimierz i Witold Piekarski. 1962. „Mistrz Wścieklica i spółka”. W Pierws飞e pokolenie marksistów polskich. Wybór pism i materiatón źródtowych z lat 1878-1886. Red. Alina Molska. Warszawa: Książka i Wiedza.

Engels, Fryderyk i Karol Marks. 1883. Manifest Komunistyczny. Tłum. Witold Piekarski. Genewa: Druk. Przedświtu.

Farr, James. 1989. "Understanding Conceptual Change Politically.” W James Farr, Terence Ball, and Russell L. Hanson. Political Innovation and Conceptual Change, 24-49. Cambridge: Cambridge University Press. 
Fourn, François. 2014. Étienne Cabet, ou, Le temps de l'utopie. Collection Chroniques. Paris: Vendémiaire.

Gałkowski, Adam. 2004. Polski patriota - obywatel Europy: rzecz o Janie Czyyńskim (1801-1867). Wyd. 1. Warszawa: Wydawn. Neriton.

Głębocki, Henryk. 2012. „Diabeł Asmodeusz” w niebieskich binoklach i kraj przyszłości. Hr. Adam Gurowski i Rosja. Kraków: ARCANA.

Goddeeris, Idesbald. 2013. La grande émigration polonaise en Belgique, 1831-1870: élites et masses en exil à l'époque romantique. Frankfurt: Peter Lang.

Gurowski, Adam. 1834. „O ruchu europejskim”. Przyszłość 1, nr 1: 17-25.

Hayat, Samuel. 2013. "La représentation inclusive". Raisons politiques 50, nr 2: 115-35. doi:10.3917/rai.050.0115.

Heryng, Zygmunt. 2007. Socjalizm pržed pót wiekiem (1875-1880) w Rosji i w Polsce: przeeżycia $i$ rozważania, red. Marta Sikorska-Kowalska. Łódź: Ibidem.

Hupfel, Simon i George Sheridan. 2015. "À la recherche d'une démocratie d'ateliers. L'Écho de la fabrique canuts". W Quand les socialistes inventaient l'avenir: presse, théories et expériences, 1825-1860, red. Thomas Bouchet, Vincent Bourdeau, Edward Castleton, Ludovic Frobert i François Jarrige. Paris: Découverte.

Jedlicki, Jerzy. 1988. Jakiej cywilizacji Polacy potrz̨ebuja: studia z. dżejów idei i wyobraźni XIX wieku. Wyd. 1. Polska XIX i XX wieku. Warszawa: PWN.

Johnson, Samuel, Alexander Chambers, Henry John Todd i John Walker. 1834. Johnson's English Dictionary. Boston: Cottons and Barnard.

Kalembka, Sławomir. 1977. Prasa demokratyczna Wielkiej Emigracji: drieje i gtówne koncepcje polityczne (1832-1863). Toruń: UMK.

Kamieński, Henryk. 1951. Pamiętniki i wiz̨erunki. Red. Witold Kula, Irmina Śliwińska. Wroclaw: Zakład Narodowy im. Ossolińskich.

Kamieński, Henryk. 1959. „Obraz porównawczy pauperyzmu”. W Henryk Kamieński, Filozofia ekonomii materialnej ludzkiego spoteczeństwa z dodaniem mniejszych pism filozoficznych, oprac. Bronisław Baczko. Warszawa: PWN.

Koberdowa, Irena. 1981. Socjalno-Rewolucyjna Partia Proletariat, 1882-1886. Warszawa: Książka i Wiedza.

Koberdowa, Irena. 1987. „Kształtowanie się wizji socjalizmu w polskiej myśli politycznej w latach 1830-1886”. W Wi żje socjalizmu w Polsce do roku 1948, red. J. Tomicki. Warszawa: Książka i Wiedza.

Kolasa, Władysław Marek. 2013. „Prasa Wielkiej Emigracji (1832-1870) w polskim prasoznawstwie”. Zeszyty Prasoznawcze 56 (3 (215)): 389-400. doi:10.4467/22996362PZ.13.022.1384.

Koselleck, Reihnart. 1998. "Social History and Begriffsgeschichte." W History of Concepts: Comparative Perspective, 23-35. Amsterdam: Amsterdam University Press.

Koselleck, Reinhart. 2001. „Historia pojęć a historia społeczna”. W Reinhart Koselleck, Semantyka historyczna. Tłum. Wojciech Kunicki. Poznań: Wydaw. Poznańskie.

Koselleck, Reinhart. 2004. "Representation, Event, and Structure.” W Futures Past. On the Semantics of Historical Time, 105-114. New York: Columbia University Press. 
Koselleck, Reinhart, Ulrike Spree i Willibald Steinmetz. 2001. „Trzy obywatelskie światy? O porównawczej semantyce społeczeństwa obywatelskiego w Niemczech, Anglii i Francji”. W Reinhart Koselleck, Semantyka historycæna. Tłum. Wojciech Kunicki. Poznań: Wydaw. Poznańskie.

Królikowski, Ludwik. 1842. „Cel modlitwy”. W Polska Chrystusowa: pismo poświęcone zasadom spotecznym. T. I, z I.

Lafaye, Pierre Benjamin. 1858. Dictionnaire des synonymes de la langue française. Paris: L. Hachette et cie.

Linde, Samuel. 1812. Stownik jezyka polskiego. T. 3: R-T. Warszawa: Drukarnia XX. Piiarów.

Longmiur, John. 1873. Walker and Webster combined in a dictionary of the English language. London: J. Campbell \& Son.

Lovell, David W. 2015. Marx's Proletariat: The Making of a Myth. London; New York: Routledge.

Lutfalla, Michel. 1967. "Sismondi - Critique de la loi des débouchés". Revue économique 18, nr 4: 654-673.

Kisluk, Eugene J. 2005. Brothers from the north: the Polish Democratic Society and the European revolutions of 1848-1849. Boulder, Colo: East European monographs.

Madelaine, Louis Philipon de la. 1823. Dictionnaire de la langue françoise: abrégé du Dictionnaire de l'Académie. Paris: J.-A. Boiste.

Marzec, Wiktor. 2016. Rebelia i reakcja. Rewolucja 1905 roku i plebejskie doświadczenie polityczne. Łódź: Universitas; Wydawnictwo Uniwersytetu Łódzkiego.

Marguery, F. 1818. Nouveau dictionnaire de la langue françoise... ou Manuel d'orthographe et de prononciation. B.m.: Raymond.

Miller, Il'â Solomonovič. 1953. „Ruch rewolucyjny i walka narodowa w Galicji w 1848 r.”. W Rok 1848 na ziemiach polskich. Warszawa: Książka i Wiedza.

Molska, Alina. 1962. „Wstęp”. W Pierwsze pokolenie marksistów polskich. Wybór pism i materiatón źródtowych z lat 1878-1886. Red. Alina Molska. Warszawa: Książka i Wiedza.

Notkowski, Andrzej. 1978. Ludwik Waryński. Wrocław-Warszawa-Kraków-Gdańsk: Zakład Narodowy im. Ossolińskich.

Pankracy. 1891. „W kwestii praktycznego programu (inteligentny proletariat)”. Pobudka: crasopismo narodowo-socyalistyczne 1.

Pepłowski, Franciszek. 1961. Słownictwo i frazeologia polskiej publicystyki okresu oświecenia i romantyzmu. Poznań: Państwowy Instytut Wydawniczy.

Perry, William. 1800. The Royal Standard English Dictionary. Boston: Thomas, Andrews.

Podolecki, Jan Kanty. 1955a. „Socjalność”. W Wybór pism z lat 1846-1851, red. Andrzej Grodek. Warszawa: PWN.

Podolecki, Jan Kanty. 1955b. „Co jest rewolucja i jakie jej stanowisko”. W Wybór pism z lat 1846-1851, red. Andrzej Grodek. Warszawa: PWN.

Rettel, Leonard. 1840. „Rozbiór dzieła Piotra Leroux o ludzkości”. Pismo TDP.

Rettel, Leonard. 1842. „Myśl demokratyczna. Harmonia ze światem”. Demokrata Polski, t. IV, cZ. III. 
Richter, Melvin. 1996. “Appreciating a Contemporary Classic: The Geschichtliche Grundbegriffe and Future Scholarship". W The meaning of historical terms and concepts. New studies on Begriffsgeschichte, red. Harmut Lehmann i Melvin Richter. Washington: German Historical Institute.

Roquefort-Flaméricourt, Jean-Baptiste-Bonaventure de. 1829. Dictionnaire étymologique de la langue françoise. T. 2. Paris: Decourchant.

Sewell, William H. 1994. A Rhetoric of Bourgeois Revolution: The Abbe Sieyes and What is the Third Estate?. Durham London: Duke University Press.

Sewell, William H. 2007. Work and revolution in France. The language of labor from the old regime to 1848. New York: Cambridge University Press.

Sierp, K. 1889. „Robotnicy galicyjscy i izby robotnicze w Austrii”. Pobudka: czasopismo narodowo-socyalistyczne 3.

Steinberg, Mark D. 1992. Moral Communities: The Culture of Class Relations in the Russian Printing Industry, 1867-1907. Studies on the History of Society and Culture. Berkeley: University of California Press.

Stenius, Henrik. 2004. "The Finnish Citizen. How a Translation Emasculated the Concept." Yearbook of Political Thought and Conceptual History, vol. 8, 172-188.

Surowiecki, Wawrzyniec. 1886. O upadku pržemystu i miast w Polsce... Poznań: Nakładem i drukiem J.I. Kraszewskiego.

Thompson, E.P. 1968. The Making of the English Working Class. New York: Vintage Books.

Trencsenyi, Balazs, Maciej Janowski, Monika Baar, Maria Falina, and Michal Kopecek. 2016. A history of modern political thought in east central Europe. New York, NY: Oxford University Press.

Worcell, Stanisław. 1854. „O własności”. W Lud polski w emigracji 1835-1846, red. Zenon Świętosławski. Jersey: Druk. Powszechna.

Wścieklica, Władysław. 1882. „Rojenia socjalistów polskich wobec nauki ich mistrza”. W Ognisko, Ksiażka zbiorowa, wydana dla uczrzenia pamięci 25-letniej pracy T.T. Ję̇a, Warszawa: Druk. K. Kowalewskiego.

Zdanowicz, Aleksander. 1861. Stownik jesykea polskiego. T. 2. Wilno: Selbstverl.

Żaliński, Henryk. 1976. Ksæ̧tałt polityczny Polski w ideologii Towarzystwa Demokratycznego Polskiego (1832-1846). Wrocław-Warszawa-Kraków-Gdańsk: Wydawnictwo Polskiej Akademii Nauk. 
Piotr Kuligowski - ur. 1990, historyk myśli politycznej, dziewiętnastowiecznik, doktorant w Zakładzie Myśli i Kultury Politycznej Instytutu Historii UAM. Zainteresowania badawcze: dzieje polskiej lewicy, procesy modernizacyjne, historia pojecc, metodologia historii. Publikował m.in. w: Klio: crasopismo poswięcone driejom Polski i powszechnym, Historia i Polityka, Historia Slavorum Occidentis, Sensus Historiae.

\section{DANE ADRESOWE:}

Zakład Myśli i Kultury Politycznej

Instytut Historii UAM

Ul. Umultowska 89 D

61-614 Poznań

EMAIL: piotr.kuligowski.1990@gmail.com

CYTOWANIE: Kuligowski, Piotr. 2017. „Ouvriers, proletrjat, czy stan czwarty? Konceptualizacje klasy robotniczej w kręgach polskiej lewicy (1832-1892)" Praktyka Teoretyczna 1(23): 160-194.

DOI: $10.14746 /$ prt.2017.1.6

FINANSOWANIE: Artykuł powstał w ramach projektu grantowego „Historia pojęć społeczno-politycznych w Polsce XVIII-XX wieku” (Narodowe Centrum Nauki, OPUS 10, nr 2015/19/B/HS3/03737), kierowanego przez prof. dr hab. Macieja Janowskiego.

AUTHOR: Piotr Kuligowski

TITLE: Ouvriers, Proletariat or the Fourth Estate? The Conceptualizations of the Working Class in the Circles of the Polish Left (1832-1892)

ABSTRACT: This article tackles the conceptualisation of the working class amongst the Polish left from the period of the establishment of the Polish Democratic Society (1832) until the convention in Paris, which resulted in the creation of the Polish Socialist Party (1892). The first part of the article concerns the period between 1832-1846. It analyses the first uses of concepts such as "proletarjat" in the Polish political language. It presents a reflective way of transferring political concepts from French. The second part of the article (1846-1878) tackles the slowdown in the process of adaptation of new concepts referring to the working class and looks at generational transformations among Polish left-wing circles. The third part of the article describes the period 1878-1892. Its aim is to show that only in the last decades of the 19th century could one speak of conceptual changes resulting from common Polish experiences. Workers in this last period were pictured as victims of capitalism, yet simultaneously as a class capable of destroying the very same capitalism.

KEYWORDS: conceptual change, political concept, the $19^{\text {th }}$ century, the political modernity, working class 